(II) Nordic Council of Ministers

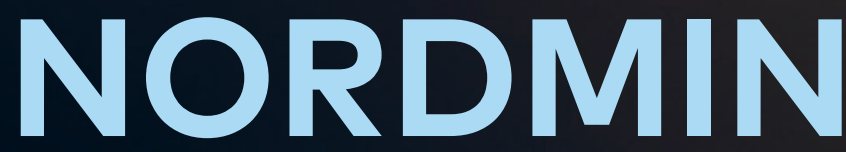

2013-2017

A Nordic Network of Expertise for

a Sustainable Mining and Mineral Industry

Final Report 



\section{NordMin 2013-2017}

A Nordic Network of Expertise for

a Sustainable Mining and Mineral Industry

Final Report

Pär Weihed and Betty Christakopoulou

TemaNord 2017:518 
NordMin 2013-2017

A Nordic Network of Expertise for a Sustainable Mining and Mineral Industry Final Report

Pär Weihed and Betty Christakopoulou

ISBN 978-92-893-4926-0 (PRINT)

ISBN 978-92-893-4927-7 (PDF)

ISBN 978-92-893-4928-4 (EPUB)

http://dx.doi.org/10.6027/TN2017-518

TemaNord 2017:518

ISSN $0908-6692$

Standard: PDF/UA-1

ISO 14289-1

(c) Nordic Council of Ministers 2017

Cover photo: Fredric Alm

Print: Rosendahls

Printed in Denmark

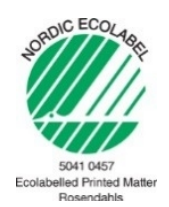

Although the Nordic Council of Ministers funded this publication, the contents do not necessarily reflect its views, policies or recommendations.

\section{Nordic co-operation}

Nordic co-operation is one of the world's most extensive forms of regional collaboration, involving Denmark, Finland, Iceland, Norway, Sweden, the Faroe Islands, Greenland, and Åland.

Nordic co-operation has firm traditions in politics, the economy, and culture. It plays an important role in European and international collaboration, and aims at creating a strong Nordic community in a strong Europe.

Nordic co-operation seeks to safeguard Nordic and regional interests and principles in the global community. Shared Nordic values help the region solidify its position as one of the world's most innovative and competitive. 


\section{Contents}

Summary

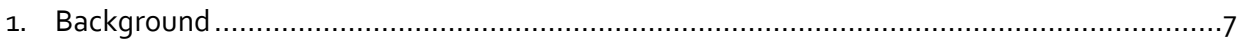

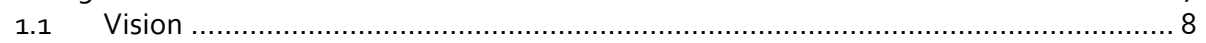

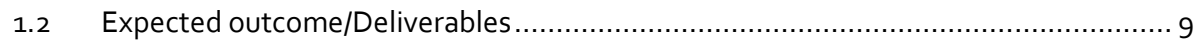

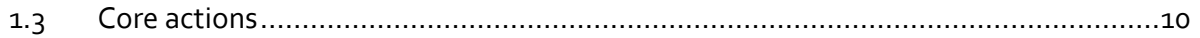

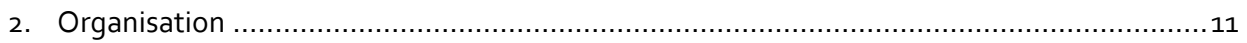

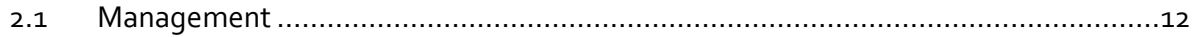

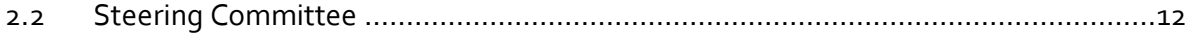

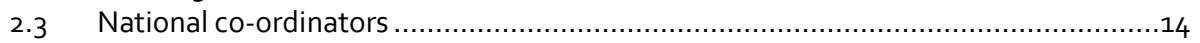

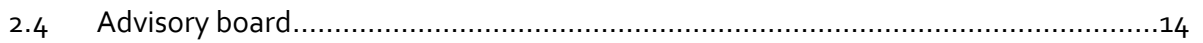

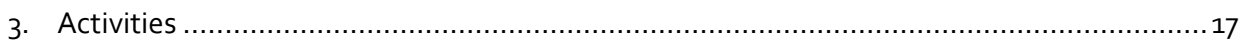

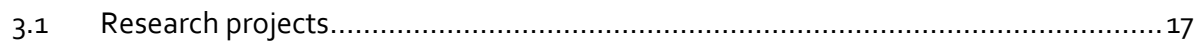

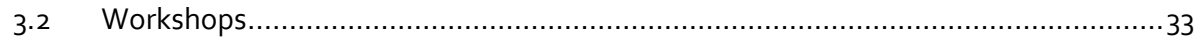

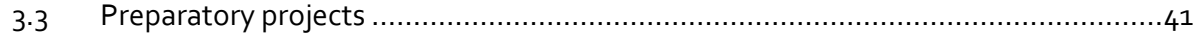

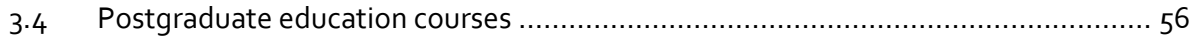

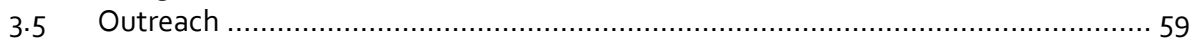

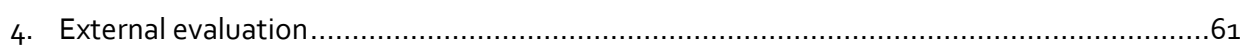

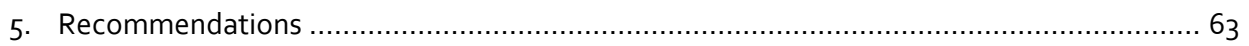

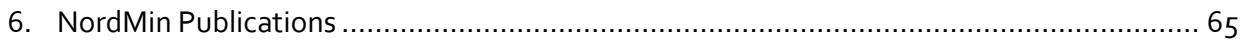

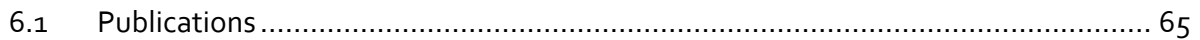

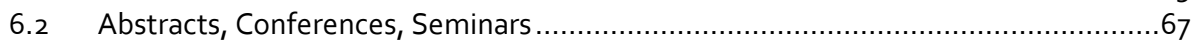

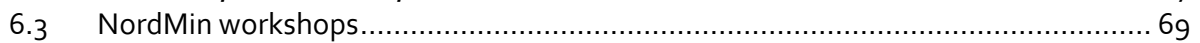

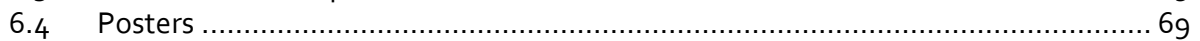

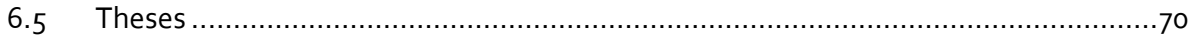

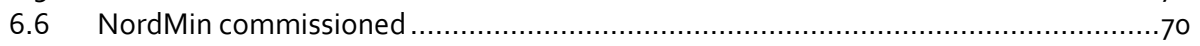

NordMin: Ett nordiskt nätverk för en hållbar gruv- och mineralindustrin ............................ 71 



\section{Summary}

NordMin started in 2013 as a project under the auspices of the Nordic Council of Ministers with the aim of strengthening collaboration for a sustainable Mining and Minerals industry in the Nordic countries.

NordMin was initiated by the Swedish chairmanship of the Nordic Council as a strategic initiative with a duration of four years.

The project management has been hosted by Luleå University of Technology and a number of activities have been rolled out over the last few years.

The NordMin project has been set up with the following key activities:

1. Research and innovation collaborative Nordic projects.

2. Workshops on predefined themes to define Nordic joint leadership on topics for further work.

3. Preparatory Nordic projects to define and submit research proposals in order to leverage Nordic funding.

4. Postgraduate courses on relevant themes.

5. Commissioned reports on sustainability criteria in a Nordic context.

The aim of this report is to provide a very brief overview of NordMin activities and also to draw some final conclusions on what has been achieved in terms of a closer Nordic collaboration within the field and how we can benefit from this in the future.

The grand challenges remaining: Supply of raw materials, sustainable development in the Arctic, energy solutions for a low-carbon society and climate change. All these issues are intimately related to the mining sector in the Nordic realm and NordMin was a first step towards finding a common Nordic agenda within the field of sustainable mineral extraction. 



\section{Background}

NordMin was a Nordic network of expertise and research focusing on sustainable nonenergy raw materials, active during the period of 2013 to 2017. The network was managed by Luleå University of Technology in Sweden. NordMin supported research, development, innovation and education initiatives in the raw materials sector across all Nordic countries and Greenland. The strength and synergy deriving from the complementary capacities of the Nordic countries was regarded as the competitive edge of NordMin. This final report summarises the activities and results of NordMin and also includes some conclusions and recommendations. For more thorough information on results from the research projects in particular, it is recommended to read the final reports from the projects (see publication list). Documentation from the project is stored at Luleå University of Technology and can be provided on request. An accompanying financial report has been submitted to the Nordic Council of Ministers and is not reported here.

The main guiding documents for setting up NordMin are the following:

- NordMin proposal for a joint Network of Expertise for a sustainable mining industry - Notat 20120706. ${ }^{1}$

- NordMin proposal for a joint Network of Expertise for a sustainable mining industry - Notat 20120830. ${ }^{2}$

- NordMin decision MR-NER 20121013. ${ }^{3}$

- NordMin Work Programme and Strategic Research and Innovation Agenda $2013-2016.4$

A comprehensive review of the start-up phase and rationale for setting up the NordMin programme by the Nordic Council of Ministers, with funding through the priority budget by the Swedish Presidency can be found in the external evaluation report. ${ }^{5}$ The information below on background is taken from this report.

In 2011, representatives from the Nordic countries came together to discuss a common action on raw materials under the name SusMin. This was then further developed into NordMin after an initiative from the Swedish Ministry of Foreign Affairs in early 2012. At this time, only the Finnish research funding agency Tekes was running a programme for the mining sector: a five-year

\footnotetext{
${ }_{1}^{1}$ Notat NR $12-005$ 17-26.

${ }^{2}$ Notat NR 12-005 17-26.

3 NordMin Decision MR-NER 12-00517-37.

4 NordMin Work Programme and Strategic Research and Innovation Agenda 2013-2016, July 2013.

5 Annika Olsson, Miriam Terrell, Markus Lindström and Erik Yläneva: Evaluation of NordMin, technopolis |group|

December 2016, $60 \mathrm{pp}$.
} 
programme called Green Mining (2011 to 2016). In the beginning of 2013, Sweden took over the Presidency of the Nordic Council of Ministers (NCM) and had the chance to, within the NCM's prioritisation budget, choose a project that could meet some of the major common challenges faced by the Nordic countries. In this setting, a Nordic networking programme in the mining area was considered important in the light of the Nordic countries' mineral resources and complementary capacities in the sector.

The project idea of a Nordic network comprising expertise and research in the mining area gained approval in October 2012. Shortly after, NCM gave Luleå University of Technology the mandate to set up a secretariat for project management and implement the programme with a funding of DKK 30.1M for three years (2013 to 2015). The NordMin networking programme was launched on January 1, 2013 to support research, development, innovation and education initiatives in the raw materials sector in all Nordic countries and Greenland.

In the beginning of 2013, when NordMin was to be implemented, the steering committee and the secretariat at Luleå University of Technology were formalised and established. In October the same year, a call for research project proposals was launched. The programme strategy was further developed by the steering committee and the programme planning document was finalised in October 2013. Due to several delays of organisational and activity-related matters during the first year, the programme period was extended from December 2015 to March 2017.

\subsection{Vision}

The vision for NordMin was to create a world-leading network for RDI in the raw materials sector.

The purpose of the NordMin network was to increase the global competitiveness and sustainability of the mining and mineral industry in the Nordic region.

The goals, as set up in the strategic research and innovation agenda, were to:

- Develop a collaborative platform for the Nordic mining and minerals industry, universities, research institutes and innovation instruments.

- Establish a "Nordic Mining School" for the coordination and cooperation of Master's and PhD programmes.

- In dialogue with industry, national research and innovation financiers, regional authority and other stakeholders, develop Nordic cooperation in research, innovation and demonstrative projects that can contribute to a sustainable mining and mineral industry.

- Create a platform for the exchange of experience on Nordic countries' mineral strategies as well as other policy areas that affect the mining and mineral industry, and to examine the need for a platform for the exchange of national authorities' lessons learned from working with the extracting industry.

- Attract external funding to a degree that makes it possible for the network to continue to thrive beyond the three years of Nordic funding, and to work to attract further investment in the network through EU funds, national funds and private investors, so the network can achieve long-term volume as described below, e.g. a budget of approx. DKK 100 million per year. 
- Address issues of mutual importance for the extractive industry and society for ensuring a sustainable mining and mineral industry in the Nordic region, including such issues as CSR, gender equality, etc.

- Increase the global visibility of the mining and mineral industry in the Nordic region.

- Initiate a broad stakeholder dialogue on the future challenges of the mining and mineral industry.

\subsection{Expected outcome/Deliverables}

The following deliverables and results were foreseen:

- Formalised academic and industry collaboration within research and innovation projects, which will result in:

- Competitive Nordic sustainable mining industry and academia with global impact and reputation.

- Improvement of best available technology and reduction of the environmental footprint.

- A Nordic critical mass in postgraduate education, based on PhD involvement in all NordMin initiatives which will lead to a stronger sector wide recruitment base.

- Increased processing of raw materials (minerals) within the region to ensure improved regional societal benefits from mining.

- Innovations that will lead to the development of new opportunities for both women and men in the sector that relate to the development of sustainable settlements in the Nordic countries.

- An established network of Nordic stakeholders in the mining and minerals area, to be maintained and mobilised for future Nordic and European actions:

- Strengthened Nordic collaboration on sustainable mining and mining innovation in a network with global impact and reputation.

- Minimising and mitigating the risk of adverse societal and environmental impact of mining and extraction.

- Contribute to a broad stakeholder debate regarding best practices for a socially sustainable, acceptable and attractive mining industry in the Nordic countries.

- An established and formalised Nordic educational collaboration within mining and minerals on Master's (Nordic Mining School) and postgraduate level. This will be achieved by, for example, the development of unique courses on subjects such as CSR, mineral entrepreneurship, mineral economy, etc.

- Joint Nordic applications and actions within the framework of Horizon 2020. 


\subsection{Core actions}

The NordMin knowledge network on sustainable non-energy raw materials had four core actions:

- Research and Innovation projects.

- Workshops.

- Preparatory projects.

- Postgraduate programme with joint Nordic MSc/PhD courses.

The "core actions", were defined on the basis of the annex 1 of the Strategic Research and Innovation Agenda. ${ }^{6}$ The core themes (see below) formed the basis for a joint call for research and innovation projects (see more under Activities - Research projects) and also formed the basis for the workshops. They were aimed at addressing topics of general importance for all countries. In conjunction with the research projects, it was also the ambition of NordMin to develop a few postgraduate courses (see below) on the "non-technological" themes of common interest to all PhD students involved (i.e. mineral entrepreneurship, sustainability of the mining sector, CSR etc.)

The following core themes were proposed in the Strategic Research and Innovation Agenda:

- $\mathrm{CT}_{1}$ : Exploration.

- $\mathrm{CT}_{2}$ : Mining.

- $\mathrm{CT}_{3}$ : Mineral processing.

- $\mathrm{CT}_{4}$ : Metallurgy.

- $\mathrm{CT}_{5}$ : Mine closure and rehabilitation.

- CT6: Socially sustainable, acceptable and attractive mining industry and regions.

${ }^{6}$ NordMin Work Programme and Strategic Research and Innovation Agenda 2013-2016, July 2013. 


\section{Organisation}

In the Strategic Research and Innovation Agenda, the organisational chart was outlined as in Figure 1.

Figure 1: Organisational chart for NordMin from the Strategic Research and Innovation Agenda

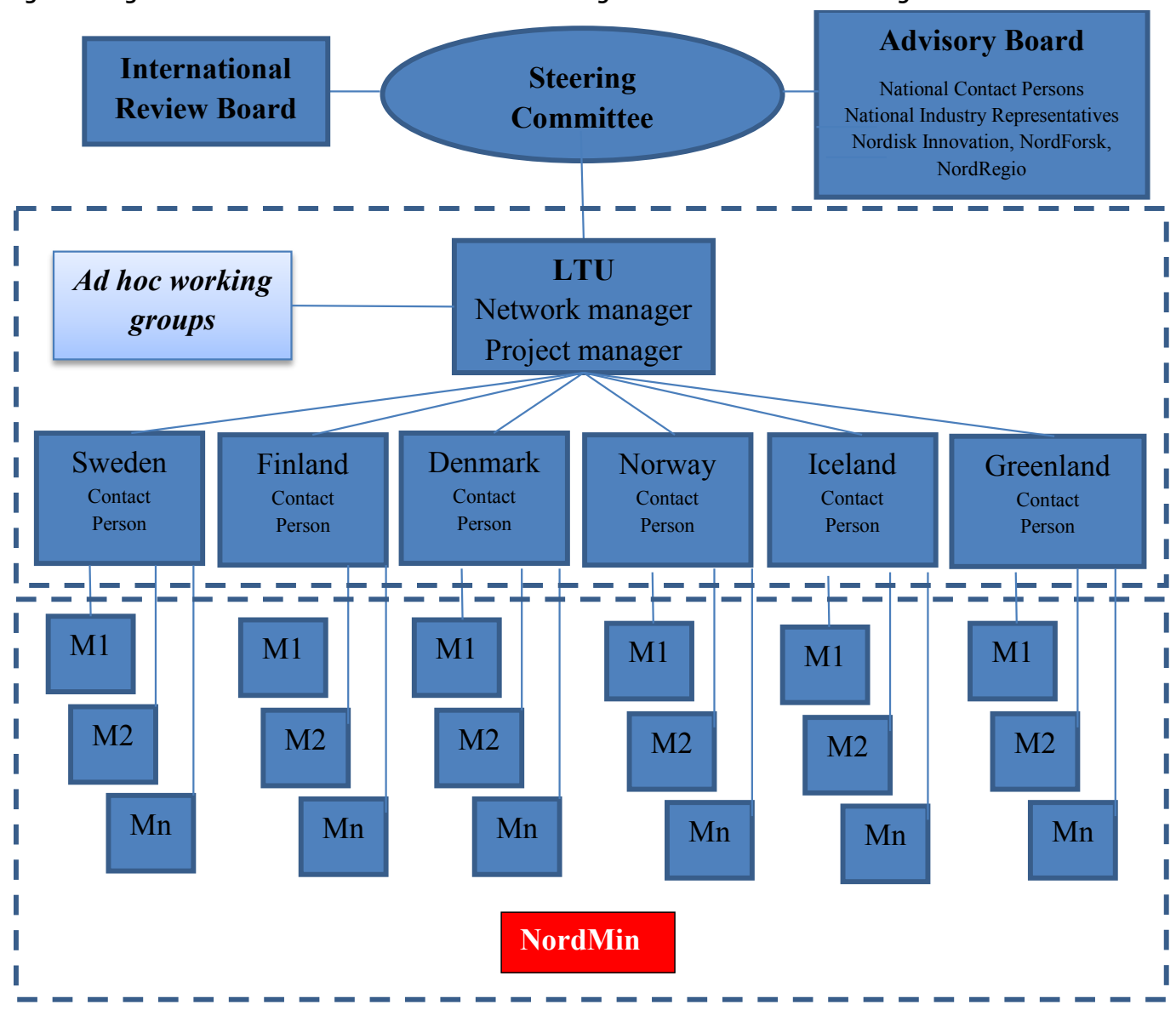

During the work with NordMin, it became clear that the organisation needed simplification and the organisation of NordMin was therefore composed of the following four core bodies:

- Network management.

- Steering Committee.

- Advisory Board.

- National contact points. 
An international review board was consulted for the evaluation of the research projects (see below) and ad hoc working groups, as described in the Strategic Research and Innovation Agenda, were not in operation.

\section{$2.1 \quad$ Management}

The network Management was hosted at Luleå University of Technology ${ }^{7}$ and was composed of a NordMin manager who was responsible for the NordMin execution. The NordMin manager worked together with a project manager/leader as an executive body. Additional resources for a NordMin secretariat were set up by LTU. The NordMin manager has been Professor Pär Weihed and the project managers Sabine Mayer and Betty Christakopoulou. Funding for Management was DKK 6.1M for the entire project period.

The duties of the NordMin Management were defined as responsibility for informing and engaging relevant actors from the Nordic countries about ongoing and planned activities. The management would also be responsible for convening the advisory board and the steering committee and for reporting to the NCM.

\subsection{Steering Committee}

The Steering Committee for the NordMin network of expertise was appointed by the participating countries and comprises six members, including one member from Greenland and one member from the secretariat of the NCM (NCMS) with observer status. The role of the steering committee was guided by the terms of reference. ${ }^{8}$ According to the terms of reference the steering committee had overall responsibility for:

- Performance of the project.

- Political relevance.

- Scientific relevance.

- Budget.

- Strategic development to promote future financing.

- Recruitment of director.

- Communications.

7 NCM 13105, 13105-3 and 13105-4.

${ }^{8}$ 12-01525-14 Final - Terms of Reference for the Steering Committee of the NordMin Project. 
The following persons were selected in October $2012^{9}$ as representatives in the steering committee:

- NO: Erlend Opstad, seniorrådgiver, Nærings- og handelsdepartementet.

- SE: Mikael Gröning, departementssekreterare, Enheten for forskning, innovation och näringsutveckling, Näringsdepartementet Chairman.

- Fl: Riikka Aaltonen, gruvöverinspektör, Närings- och innovationsavdelning, Arbets- och näringsministeriet.

- IS: Bryndís G. Róbertsdóttir, Manager - mineral resources utilization, Orkustofnun - National Energy Authority.

- $D K$ : Flemming Getreuer Christiansen, Vicedirektør i GEUS.

- GR: Bente Vibeke Hansen, Head of section, Bureau of Minerals \& Petroleum.

- NCM: Kenneth Ekberg.

Mikael Gröning was replaced by Katarina Persson Nilsson, from the Ministry of Enterprise, as Chairperson in January 2016 when he left the Ministry for a position within industry.

Erlend Opstad was replaced by Petter Herdlevær Sagafos in September 2016.

Bente Vibeke Hansen was replaced by Mathias Barfod in April 2014.

Kenneth Ekberg was replaced by Mai Fersløv/Lise Østby in August 2016.

The steering committee has held regular meetings (three per year) in different locations in the Nordic countries. Each meeting was documented in minutes. The minutes are available on request from LTU.

By decision of the Steering Committee, a study on the sustainability criteria of the Nordic mineral sector was undertaken. The study was executed by Luleå University of Technology and was divided into a pre-study on mining legislation and taxation in the Nordic counties by Hojem (2015) ${ }^{10}$ and a full project on sustainability criteria for the Nordic extractive industry, ${ }_{1}^{11}$ which is described under research projects below. Below is the summary of the pre-study:

For historic reasons, the Nordic countries share a lot of similarities in legislation. And not least with regards to environmental laws, the EU has contributed to further harmonisation, even among the non-member states of Iceland and Norway. Yet important differences exist. Legal revisions are sometimes the result of much-publicised problems, so experiences in each country play an important role. For example, Norway has given its Sami population and municipalities a stronger say. The Finnish Mining Act includes provisions for mandatory mine safety permits. Denmark and Iceland have relatively smaller mineral industries, which is also reflected in the focus of their subsoil raw material laws. Greenland is perhaps the greatest outlier with regards to legal framework. For example, it does not differentiate between landowner and state-owned minerals, and Social

9 12-01525-1 NordMin styrelse.

${ }^{10}$ Hojem, P. (2015). Mining in the Nordic Countries: A comparative review of legislation and taxation. TemaNord 2015: 542. $84 \mathrm{pp}$.

${ }^{11}$ Ranängen et al. (2016). A path towards sustainability for the Nordic mining industry. TN2016:560, 96 pp. 
Impact Assessments and negotiated Impact Benefit Agreements are standard requirements, unlike in its Nordic neighbours.

An overview of taxation also indicates both similarities and differences: Finland and Sweden are ranked as having among the lowest effective taxes on mining internationally, while the rate in Norway seems to be somewhat higher. Greenland is an outlier here too, with high royalties in a Nordic context. The Greenlandic level is, however, more comparable to the global median. At the same time, comparisons should be considered with care, as a range of taxes as well as possible tax deductions play an important role in the actual outcome.

\subsection{National co-ordinators}

National co-ordinators were appointed to be the national liaison persons for NordMin. In this role, the co-ordinators distributed information concerning NordMin in each country and were responsible for the contact between stakeholders and NordMin at a national level. The national co-ordinators convened on a regular basis and minutes from the co-ordinators meetings are available from Luleå University of Technology upon request.

The national co-ordinators were:

- Sweden:

- Pär Weihed; Luleå University of Technology (LTU).

- Norway:

- Jack Ødegård/Per Helge Høgaas; SINTEF Materials and chemistry.

- Denmark \& Greenland:

- Karen Hanghøj/Per Kalvig; Geological Survey of Denmark and Greenland.

- Finland:

- Maija Uusisuo; Ministry of Employment and the Economy.

- Iceland:

- Bryndís Guðrún Róbertsdóttir; Orkustofnun Icelandic National Energy Authority.

- Greenland:

- Hans Hinrichsen; Greenland School of Minerals and Petroleum.

\subsection{Advisory board}

According to the Strategic Research and Innovation Agenda, the Advisory Board should consist of two persons per country and Greenland, representing industry and academia. The national Contact Persons could hold one of the two positions in each country. The Nordic research institutes, Nordforsk, Nordregio and Nordisk Innovation should also have one person per institute in the Advisory Board. The task of the Advisory Board was to advise the Steering Committee on the activities that were planned within the 
network, e.g. organisation, monitoring and evaluation of workshops, courses and preparatory projects. The Management should convene the Advisory Board. The project management still had the overall responsibility to inform and engage relevant actors from the Nordic Region.

Besides the National co-ordinators, the Advisory board consisted of:

- Per Ahl-SveMin, Sweden, SE.

- Katarina Nilsson, Geological Survey of Sweden, SE (until end 2015).

- Pekka Suomela - The Federation of Finnish Technology Industries, FI.

- Vigdís Harðardóttir - Island Geo-survey, IS.

- Prof. Porvaldur Pórðarson - Faculty of Earth Sciences, University of Iceland, IS.

- Gunnel Gustafsson - Nordforsk, Oslo, NO.

- Roger Bjørgan - Nordic Innovation, Oslo, NO.

- Kjell Nilsson - Nordregio, NO.

- Jonas Ivarsson, Nordic Innovation, NO.

- Olli Salmi, VTT, FI.

- Kristin Husebø Hestnes/Elisabeth Gammelsæter, Norsk Bergindustri, NO. 



\section{Activities}

\subsection{Research projects}

Research and Innovation projects were developed within the core themes on the basis of the NordMin Strategic agenda. A call for research project proposals was launched in the autumn of 2013 . Following the evaluation of the submitted proposals from an international review board, five research projects, covering all NordMin core themes, were granted funding from NordMin. The projects started working in April 2014, and they ran for 30 months, until the end of September 2016. All these R\&D projects involved cross-nation collaboration and were characterised by the following:

- Representation from at least three Nordic countries.

- Industrial active involvement.

- Inclusion of minimum one post-graduate student.

- Plan stating objectives, milestones and modes of dissemination of outcomes.

- NordMin contribution to the total project costs, maximum $70 \%$, and not exceeding the $5 \mathrm{M} \mathrm{DKK/project.}$

The six research projects funded by NordMin were:

- CRUSMID-3D.

- GREENBAS.

- PlatinumProbe.

- SEARCH.

- WASCIOUS.

- Sustainability Criteria for the Nordic Extractive Industry.

Each project is briefly described below. 
3.1.1 Crustal Structure and Mineral Deposit Systems: ${ }_{3} D$ modelling of base metal mineralisation in Jameson Land and nickel mineralisation in Disko-Nuussuaq (CRUSMID-3D)

- Coordinator: Geological Survey of Denmark and Greenland - GEUS (DK).

- Project leader: Pierpaolo Guarnieri (pgua@geus.dk).

- Participating organisations: Iceland Geosurvey - ISOR (IS), Luleå University of Technology - LTU (SE), Avannaa Resources Ltd.

- NordMin funding: DKK $2.17 \mathrm{M}$.

Providing research and education at a high international level is a prerequisite for the raw material sector to develop competitive and cost-effective exploration methods. The NordMin project CRUSMID-3D was a consortium between research institutes, academia and SMEs, supporting a PhD project to study some of the geological processes in Greenland that were related to ore deposits, in order to understand the relationships between structures and mineralisation. The new geological and structural data together with aeromagnetic/electromagnetic surveys and the drill-core data added new values to the regional knowledge of East Greenland. The exploration tools developed within the PhD project are expected to be useful in planning and executing future exploration campaigns in similar but also other geological environments.

CRUSMID-3D has resulted in a better understanding of the relationships between intrusions, hydrothermal fluid-bearing mineralisation and the tectonic setting in central East Greenland. The project has also led to increased knowledge of how small and large-scale mineralising systems operate and how this information can be used in exploration targeting. Furthermore, CRUSMID-3D has accomplished $3 \mathrm{D}$ geophysical modelling of base metal mineralisation in Jameson Land (East Greenland). Greenland Gas and Oil Ltd is interested in the outcome and further collaboration. 
Figure 2: Geological map of the Jameson land Basin (modified after Kokfelt et al., 2013). The letters refer to localities of Tertiary intrusions (B) Kap Simpson, (C) Kap Syenit, (D) Oksehorn, (E) Werner Bjerge and (F) Malmbjerg. The contours of aeromagnetic surveys are plotted in black.

From Guarnieri et al. $2016^{12}$

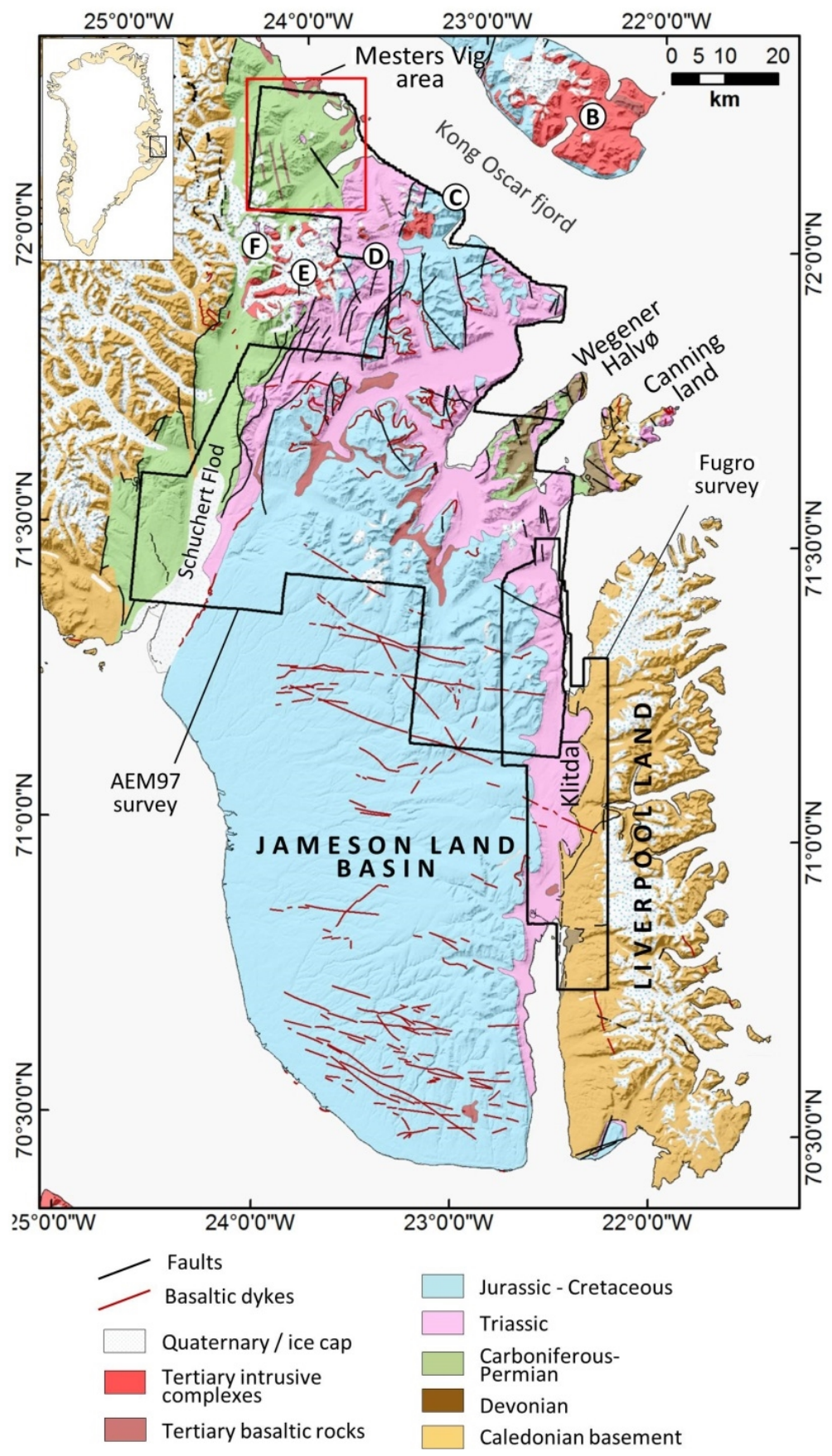

${ }^{12}$ Guarnieri et al. 2016: CRUSMID-3D final report, NCM Tema Nord publication TN2016:562, 174 pp. 


\section{Conclusions}

A comprehensive final report ${ }^{13}$ is available from the project leader Pierpaolo Guarnieri, GEUS, upon request. Below is the conclusion from the final report. Publications from the project are listed at the end of this final NordMin report.

"The CRUSMID-3D project conducted over the last two and a half years treated several thematics using cross-disciplinary methods in order to investigate the crustal structures and mineralisation systems in the Jameson Land Basin in central East Greenland. The scientific questions addressed and results obtained are summarised in the following paragraphs.

(1) One study aimed at reprocessing and interpreting all available magnetic data in the Jameson Land area to extract geological features at the surface or at depth in order to outline the regional structures of the basin and delineate the local structures in areas where mineralisation is structurally controlled. Some highly positive magnetic anomalies are associated with Tertiary plutonic intrusive complexes, one of which is the Malmbjerg molybdenum deposit. Several other high magnetic anomalies were identified and could also be associated with shallow plutonic Tertiary intrusions. Many magnetic lineaments were delineated are classified into four main orientation trends: N-S, NE-SW, EW and NW-SE. Some of them were correlated with Triassic lamprophyres, tertiary lamprophyres and Tertiary doleritic dykes and sills, while others could be correlated with different fault systems. This not only allowed a better overview of the regional structures of the northern part of the basin to be obtained, but also to find trends that are associated with mineralisation such as N-S trending faults in the northernmost part of the Klitdal area.

(2) The second study aimed at developing a new procedure to analyse and synthetise geological information from the magnetic signal decomposition. Various maps enhancing specific geological features, in different directions and at different depths were analysed using a SelfOrganising Maps approach. Magnetic signal patterns were defined by correlating the geological knowledge of the area with a characteristic magnetic signal. This method firstly allows the enhancement of subtle magnetic features, barely visible on commonly used magnetic signal maps. Discontinuities within magnetic signal patterns within adjacent locations are identified using averaging errors inherent to the data reduction procedure and allowing for the identification of faults. Secondly, this approach enables interpreting magnetic data in a more systematic and objective manner.

This method was tested in the Mesters Vig area, in the northern part of the Jameson Land Basin, where $\mathrm{Pb}-\mathrm{Zn}$ vein type mineralisation occurs. Dykes were identified and mapped over the entire area and the intensity of their signal compared to the geology. This allowed the definition of areas where they are blind and therefore to define which part of the stratigraphic pile is intruded. Faults were mapped and four fault orientation families were characterised, one of which is known to control the vein mineralisation.

(3) The third study aimed at constraining the architecture and estimating the thickness of the basin along the eastern margin. For this 3D photomapping, field imagery of magnetic and electromagnetic data and structural measurements along with drilling results were integrated to build a $3 \mathrm{D}$ geological and petrophysical model of the area. Investigative 2D magnetic modelling was performed to constrain the architecture of the basin, and the surface of the magnetic basement was modelled using a $3 \mathrm{D}$ geologically constrained inversion of the magnetic data.

The Klitdal area is divided in two main blocks by a NE-SW fault called the Klitdal fault. The southern block has a shallow crystalline basement, peneplained and tilted a few degrees to the west and is onlapped by Triassic sediments. The northern block is down-faulted and inversion results suggest that a sedimentary package of more than 200om is lying on top of the crystalline basement. A very thick sequence of syn-rift coarse Early Triassic sediments might be present offering a good

${ }^{13}$ Guarnieri et al. (2016). CRUSMID-3D final report. NCM Tema Nord publication TN2016:562, 174 pp. 
permeability and source of base metals but the lack of Upper Permian black shales in this area as a reducing agent could possibly be the reason for the absence of obvious mineralisation in the Klitdal area, as opposed to areas further north such as in the Wegener Halvø area.

(4) The fourth study aimed at mapping and understanding the cause of the induced polarisation (IP) effects that occur in airborne Time Domain EM (TEM) data acquired along the eastern margin of the basin. IP indicators were extracted from the shape of the transient curves at every measurement location and were analysed using a Self-Organising Map (SOM) procedure. Transient curve patterns were clustered, plotted on a geographical map and correlated with the geology. We identified five areas affected by strong IP effects. Two of them present IP effects at a stratigraphic level known to host copper sulphides at the boundary between the Early Triassic Pingodal formation and the Late Triassic Gipsdalen formation. Magmatic activity is observed in the area and could be an important parameter regarding the presence of IP. Two other areas affected by IP effects occur where the Upper Triassic Fleming fjord formation is outcropping. One of the areas is $\mathrm{N}$-S elongated and the transient curves present symmetric characteristics across the N-S axis. This could be associated with a small graben or intra-basin depression filled with polarisable material, possibly clays. At these localities, TEM sections were inverted for the Cole-Cole parameters, as the analysis of the resistivity, chargeability, time constant and frequency dependence would help to discriminate between possible sources of IP effects such as the presence of sulphides, clays or permafrost. The stage of the inversion procedure does not allow for conclusions to be drawn yet but provides a spatial definition of the IP source bodies.

(5) The Triassic rift along the East Greenland margin described in this report is represented by NE-SW trending basin and highs segmented by NW-SE trending transfer zones. Coarse-grained sediments along the eastern side of Jameson Land are shown to be hosted in half-graben structures belonging to the Carlsberg Fjord Basin that is bounded by NW-dipping normal faults mapped and described after fieldwork in the Klitdal area in Liverpool Land. New aeromagnetic and electromagnetic data together with new drill cores allowed for the reinterpretation of available seismic lines showing the continuation of the Triassic rift basin toward the SW, where it is buried under the Upper Triassic post-rift sediments and the Jurassic sequences of the Jameson Land Basin. The N-S trending Liverpool Land, thought to be the boundary block of the Triassic basin, is shown to be a structural high inherited from the Upper Carboniferous tectonics down-faulted during the Triassic rifting. The Carlsberg Fjord Basin and the Klitdal Fault System described in this report should be seen as analogous to the Helgeland Basin in the Norwegian offshore that is bounded by the Ylvingen Fault Zone and to the Papa and West of Shetlands Basins that are bounded by the Spine Fault. The Triassic rift zone on both conjugate margins shows a straightforward correlation with the trend of the main normal faults and fracture zones of the North-East Atlantic rift and the initial spreading line, suggesting a legacy of the Triassic rifting."

\subsubsection{Sustainable Fibres from Basalt Mining (GREENBAS)}

- Coordinator: Innovation Center Iceland - ICI (IS).

- Project leaders: Birgir Johannesson (birgirj@nmi.is) and Thorsteinn Ingi Sigfusson (this@nmi.is).

- Participating organisations: Iceland Geosurvey - ISOR (IS), Reykjavik University RU (IS), JEI Jarõefnaiõnaõur (Íslenskur Jarðefnaiðnaður) (IS), SINTEF (NO), VTT (FI).

- NordMin funding: DKK $4.83 \mathrm{M}$.

The GREENBAS project related to the feasibility of producing continuous basalt fibres from basaltic lava mined in Iceland. Three Nordic countries were involved with support 
from NordMin, with the overall aim of developing the Nordic mining and mineral industry in a sustainable way for increased competition and growth.

Geological investigations by Iceland Geosurvey (ISOR) have resulted in greater insight into where to search for the most ideal materials. Research by Innovation Centre Iceland $(\mathrm{ICl})$ led to the definition of the conditions of the chemical composition of the mined ore following probing of 154 areas in Iceland. $\mathrm{ICl}$ also analysed the business conditions for a start-up factory in Iceland. The involvement of the mining company JEI in Iceland has ensured industrial relevance in conjunction with the contribution of the University of Reykjavik's team in gaining an understanding of the importance of continuous fibres in various building materials in Iceland.

The involvement of experts from SINTEF Norway and VTT Finland was crucial to this work. They provided their expertise in analysing the life-cycle of basalt for fibre production, and the feasibility and need of artificial external components.

GREENBAS has assessed the applicability of Icelandic basalt for the production of Basalt fibres for industrial applications, something of potential interest for both the plastic and asphalt industries. According to a business model that has been set up for a plant producing basalt fibres in Iceland, the potential is large and the efforts continue to find an optimal material composition for almost completely carbon footprint-free Basalt fibre production, based on green energy. It is now possible, on the basis of this project, to start a new phase: the preparations for establishing a continuous volcanic basal fibre factory in Iceland.

Figure 3: Simplified geological map of Iceland and location of samples. From Johannesson et al. $(2016)^{14}$

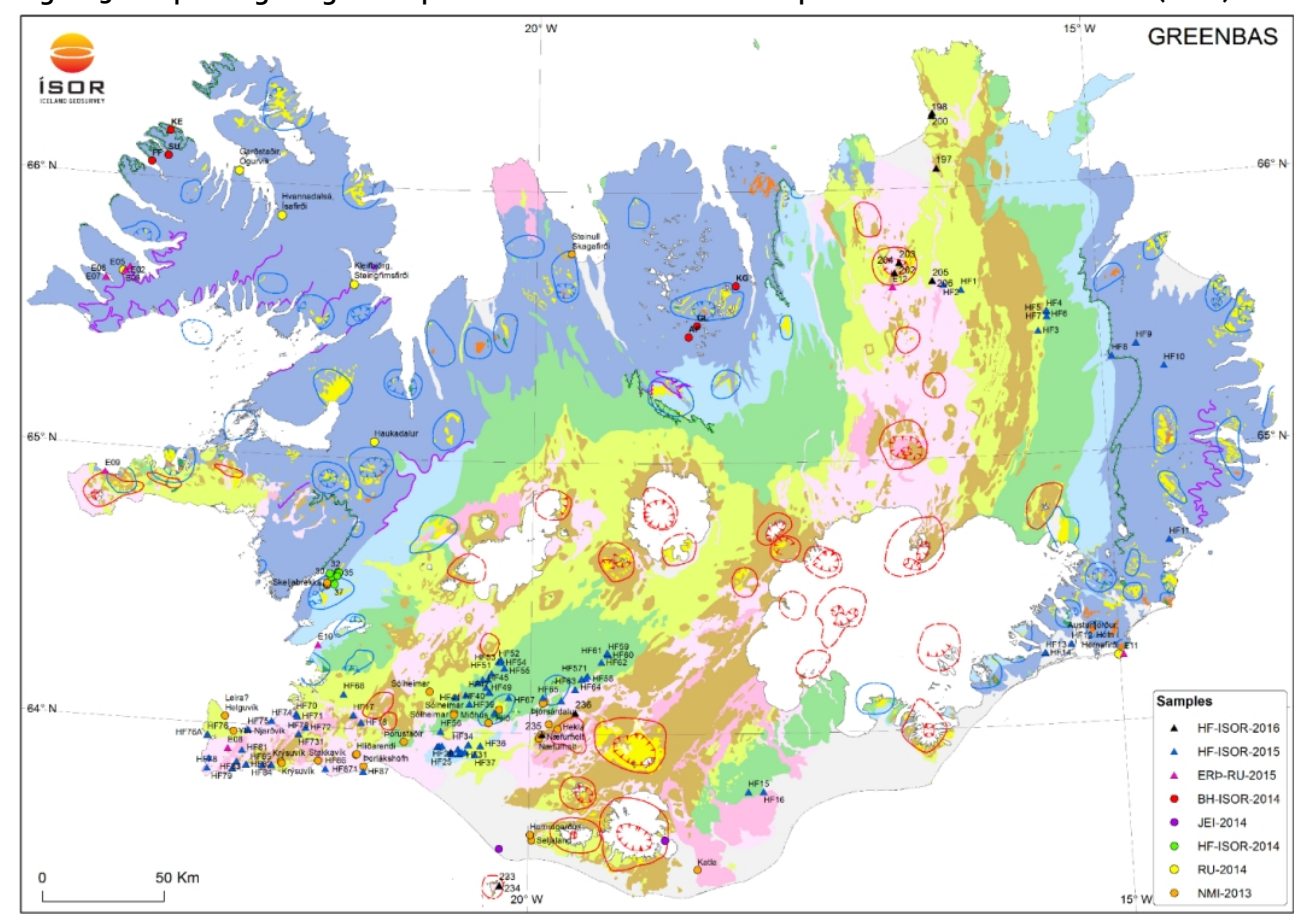

${ }^{14}$ Johannesson et al. (2016). GREENBAS final report. TemaNord publication TN2016:564, $61 \mathrm{pp}$. 


\section{Conclusions}

A comprehensive final report ${ }^{15}$ is available from the project leader, Birgir Johannesson, $\mathrm{ICl}$, upon request. Below are the conclusions from the final report. Publications from the project are listed at the end of this final NordMin report.

6. A literature review, in addition to discussions with scientists in the field, has revealed the criteria for the composition and other properties that basalt has to meet in order to be suitable for production of CBF.

7. A total of 154 samples of Icelandic basalt have been collected. Measurement of the chemical composition and evaluation of material parameters such as acidity and viscosity moduli have shown that samples with andesite containing more than $50 \%$ wt. $\mathrm{SiO}_{2}$ are best suited for production of CBF.

8. Three samples have been chosen for the final stage of the selection process. The addition of burnt lime $(\mathrm{CaO})$ is necessary to modify the chemical composition of these specimens in order to make them suitable for production of CBF.

Experiments are being carried out on the modified material to determine its suitability for production of CBF.

9. The viscosity of two of the samples was measured by Anton Paar in Austria. These measurements showed that both samples have the required viscosity in the required temperature interval to qualify for fibre drawing.

10. Icelandic basalt contains a fairly high amount of iron oxide. A simple experiment on magnetic separation of a powdered sample was performed. The results of that experiment show that the material reacts strongly to a magnet. Further work is required to estimate the viability of using magnetic separation in order to reduce iron oxide content in Icelandic basalt.

11. A rudimentary business model has been set up for a plant producing CBF in Iceland. The initial results show that for a plant producing 50 tons per year, the price of CBF needs to be at least EUR 11/kg in order to break even.

\subsubsection{Modelling dunite hosted PGE- Ni- Cu deposits in the Seiland} Igneous province (PlatinumProbe)

- Coordinator: Norwegian University of Science and Technology - NTNU (NO).

- Project leader: Rune Larsen (rune.larsen@ntnu.no).

- Participating organisations: NM Nordic Mining Industry ASA (NO), AU Århus University (DK), MI Geoconsulting OY (FI).

- NordMin funding: DKK $1.98 \mathrm{M}$. 
The purpose of PlatinumProbe was to unravel the genesis of a new type Ni-Cu-Au-PtOs reef deposit that is hosted in the dunitic part of an ultramafic intrusion in the Seiland Igneous Province (SIP) in N-Norway, as two reef deposits over only 20 metres of stratigraphy.

The project was divided into three main parts:

- Part 1: Origin of the parental melts forming the reef deposits.

- Part 2: Formation of the reef deposits.

- Part 3: Geophysical studies of host intrusion and reef deposits.

PlatinumProbe has resulted in an increased knowledge in the genesis, size and economic potential of copper, nickel and precious metal deposits in the Seiland Igneous Province in northern Norway.

Better ore-genetic models combined with a fine-tuned interpretation of the geophysical pattern fingerprinting the deposits, will significantly increase the confidence in evaluating the ore-forming potential elsewhere in SIP and in similar settings worldwide.

The project has, among other aspects, resulted in prospecting models for the discovery of new sulphide deposits.

\section{Conclusions}

A comprehensive final report is available from the project leader Rune Larsen, NTNU, upon request. Below is the conclusion from the final report. Publications from the project are listed at the end of this final NordMin report.

1. Over the course of the PlatinumProbe project, we managed to collect two drill cores of, respectively, 398 and 348 metres. We had two field-campaigns with nine participants in 2014-15. A total of c. 350 samples were analysed for major and trace elements and c. 85 polished petrographic thin sections were produced for SEM and EPMA and other in situ mineral analyses. Moreover, $15 \mathrm{~km}^{2}$ of RUC was remapped with absolute positioning techniques. Tens of profile kilometres of ground geophysical data including gravimetric and magnetic data were sampled together with c. 120 diamond drill bits c. $10 \mathrm{~cm}$, each were sampled for paleomagnetic studies.

2. RUC comprises a volcanic feeder conduit system accommodating hundreds perhaps thousands of $\mathrm{km}^{3}$ of hot $\left(1,400-1,450^{\circ} \mathrm{C}\right)$ picritic to komatiitic melts. It is characterised by multiple recharge events of fresh fertile melts that contain a high abundance of $\mathrm{Cu}, \mathrm{Ni}$, PGE's and $\mathrm{Au}$ and was at, or close to, sulphide saturation when they passed through RUC.

3. 3 Cu-reefs, 5 PGE-reefs and 1 Ni-reef formed over c. 400 metres of dunitic stratigraphy. The reefs are decoupled, i.e. conditions favoured either the formation of $\mathrm{CU} \pm \mathrm{Ni}$ reefs or $\mathrm{PGE}+\mathrm{Au}$ reefs. 
4. $\mathrm{Cu} \pm \mathrm{Ni}$ reefs formed during transient closed system conditions when relatively sulphide droplets deposited relatively fast (low $\mathrm{R}$-factor).

5. PGE-Au reefs formed in more open system where the repetitive recharge of fertile sulphide oversaturated melts kept small droplets of sulphide in suspension and ensured the tapping of PGE+Au from large volumes of silicate melts (High R-factor).

6. The reefs are sub-economic but very thick (5-10 metres) and typically formed where swelling of the conduit system formed embayments with less turbulent conditions favouring deposition of sulphide reefs.

7. The main conduit, continuous towards depth and deep-seated embayments, could be targeted for sulphide reefs.

8. There are three other large ultramafic complexes in SIP. They have the same composition and magmatic evolution as RUC but are $3-6$ times larger.

Accordingly, more sulphide-melt is produced that was in contact with, and tapped, much larger volumes of silicate melt. The possibility for finding larger deposits in these complexes should not be ignored.

9. Regional gravimetric modelling demonstrated that SIP has four major conduit systems continuing to $>9 \mathrm{~km}$ 's depth and underline our theory that tens of thousands $\mathrm{km}^{3}$ of mafic and ultramafic igneous melts passed from the asthenospheric mantle, through SIP and onwards towards the surface. Accordingly, SIP may represent the lower crustal part of a volcanic system that formed a Large Igneous Province (LIP) at the surface. 
Figure 4: Revised geological map produced during the PlatinumProbe project. The four green stars mark the position of the Nordic Mining drill holes $\left(R_{1}, R F_{2}\right)$ and the PlatinumProbe drill holes $\left(\mathrm{RF}_{3}\right.$, $\mathrm{RF}_{4}$ ). Cu-Ni-PGE-Au reef deposits were located in $\mathrm{RF}_{1}, 3$ and 4
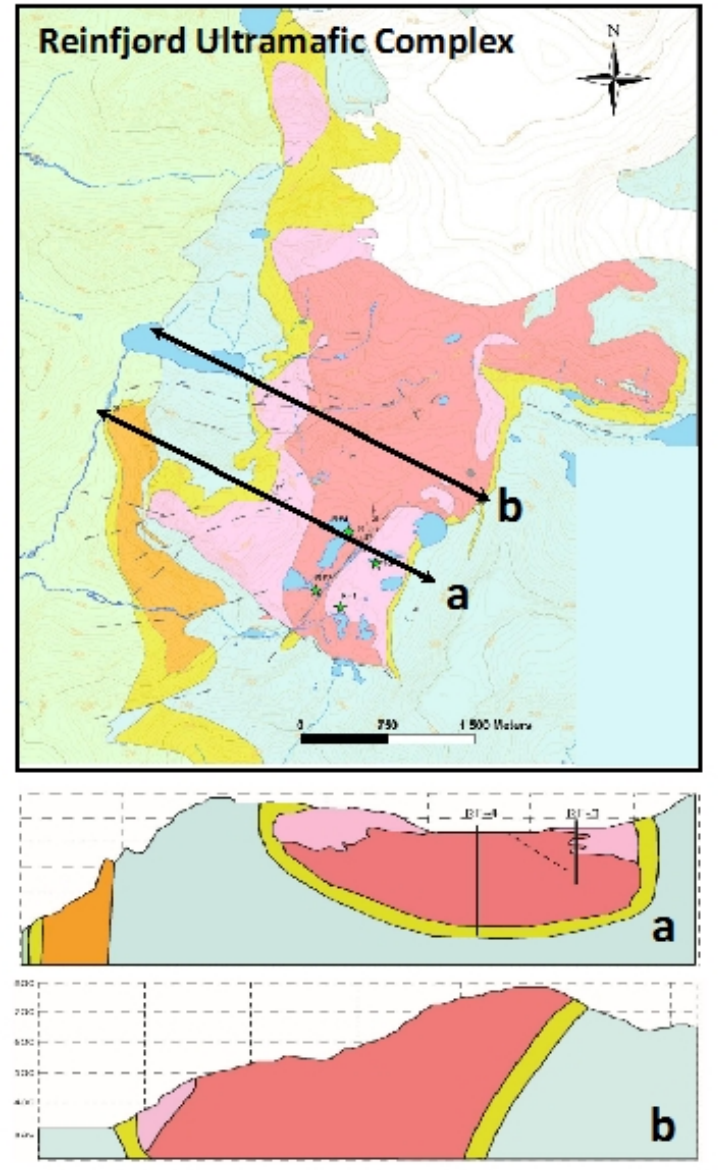

Gabbro

Olivine-Clinopyroxenite

Marginal Zone (Hybrid Zone)

Wehrlite (Reinfjord)

Dunite (Reinfjord) 

interventions (SEARCH)

- Coordinator: Luleå University of Technology - LTU (SE).

- Project leader: Eira Andersson (eira.andersson@Itu.se).

- Participating organisations: Nordland Research Institute, NRI (NO), Oulu University, the Oulu School of Architecture, OSA (FI), LKAB, Boliden (SE), Kunnskapsparken Bodø AS/Mining \& Mineral Cluster Norway, MMCN (NO). Dannemora Mineral (SE) and Northland Resources (SE) were part of the initial phase of the project before closing down their operations.

- NordMin funding: DKK $1.81 \mathrm{M}$.

Gender equality is central to promoting and intensifying sustainable development in the Nordic mining and mineral sector. Industry, academia and policy makers are addressing the predicament of the male-biased mining sector and the need for new actions. The aim of the SEARCH project is to examine gender patterns and gender equality initiatives in Nordic mining. The main objective is to identify successful approaches and to design guidelines for a new best practice. The long-term goal is to create attractive, effective and equal organisations supporting sustainable development in mining and Nordic mining regions. A further ambition is to increase the global visibility of the mining industry in the Nordic region as a world-leader in gender equality. The SEARCH project includes research partners at Luleå University of Technology, LTU (Sweden), also coordinating the project; Nordland Research Institute, NRI (Norway) and the Oulu School of Architecture, OSA (Finland) as well as industry partners; LKAB, Boliden (Sweden) and Kunnskapsparken Bodø AS/Mining \& Mineral Cluster Norway, MMCN (Norway).

In the SEARCH project, the researchers have studied gender patterns (quantitative and qualitative) in major Nordic (Sweden, Norway and Finland) mining companies; identifying male-biased structures and practices but also new discourses concerning gender equality, progress regarding the number of women and various equality measures. However, due to difficulties with access to mining companies, especially in Norway and Finland, and the lack of open, available or existing documentation, activities and research have generally been focused on Sweden and the project's industry partners, LKAB and Boliden. As a focal activity in the project interviews with HR managers (or equivalent) were conducted, to define what professionals identify as important gender equality initiatives. An analysis of policy documents concerning gender equality has also been carried out. In addition, interviews with mining workers were conducted, to form an understanding about attitudes concerning gender equality. Furthermore an Internet-based enquiry was directed at LKAB to mining workers and their families, to compile factors/preferences on living environment and quality of life in the mining municipalities. Ultimately, various measures for gender equality have been analysed in relation to the gender research field and in dialogue with industry partners, in order to identify successful approaches and ways for improvement. 
Based on the findings, a recommendation for the future is to focus on critical issues of gender equality in-house, at an organisational level, where the industry could currently make changes. The project illustrate two novel gender equality initiatives, one targeting women's minority positions at work and one targeting norm criticism, as inspiration. The findings also point to the overall lack of systematic approaches concerning gender equality. The project proposes a model for gender equality actions, based on a situation assessment and importantly evaluation of results, in line with development work as such. Grounded in such procedures for equality work, companies can identify success indicators and learn for the future, also emphasising Nordic mining as leading in gender equality on a global arena.

\section{Conclusions}

The findings from the SEARCH project highlight the bias in favour of men in mining, globally and also in the Nordic countries. The industry is exceedingly male dominated, meaning that men have the most access to its benefits such as employment and income. In large Nordic mining companies today in Sweden, Norway and Finland, the total number of women varies between $10-19 \% .{ }^{16}$ Moreover, it is not only through numbers that men are dominating mining, masculine ideals such as a certain type of "macho-masculinity" have dominated structures, practices and procedures for bluecollar working professionals as well as professional ideals of mining.

Although the Nordic mining industry still displays gender-biased patterns, structures and discourses, the industry is undergoing fundamental changes. Gender equality is on the agenda and part of the daily discourse, initiated by the industry itself, human resources policies and strategies, and by academic institutions and policymakers. In Sweden, LKAB and Boliden are working strategically with gender equality in terms of various initiatives (e.g., wage mapping, women's networks, genderawareness training programs, etc.). Nonetheless, one problem is that the industry still capitulates to outside circumstances (e.g. we have no women in mining because women do not educate themselves in this field), and many previous efforts are underpinned by the assumption that merely increasing the number of women would contribute to a change.

It is now time to be more innovative and to find areas inside, at an organisational level, where the Nordic mining companies can act and make changes. Recommendations for the future are to focus on critical issues of gender equality inhouse; women's minority positions at work and initiatives targeting norm criticism are examples of areas for improvement. In the SEARCH project, we illustrate two novel gender-equality initiatives, one targeting women's careers in mining and one targeting blue-collar workplace culture, as inspiration for action.

Overall, and most importantly, the SEARCH project points to the lack of systematic approaches concerning gender equality work in Nordic mining. The industry cannot engage in a process of change without proper procedures for gender equality and the evaluation of prior activities. The SEARCH project proposes a project model for gender

\footnotetext{
${ }^{16}$ The numbers are not conclusive, as the gender-division statistics in the mining industry are insufficient.
} 
equality actions, in line with existing development models in the industry. The model originates from a situation assessment, from a gender perspective, to identify objectives and specific problem areas. Gender statistics, specific and comprehensive, are a good way to start such an analysis. However, the SEARCH project also reveals that gender division statistics, at an organisational level and concerning the mining industry nationwide, are often substandard. The industry must start at the very beginning, to document and analyse the current situation, quantitative and qualitative, and also the result of new actions. This knowledge will form the basis for future gender equality interventions and a sustainable development of the Nordic mining industry, also emphasising mining in the Nordic region as leading in gender equality on a global arena. Publications from the project are listed at the end of this final NordMin report.

\subsubsection{Water Conscious Mining (WASCIOUS)}

- Coordinator: Technical Research Center of Finland (VTT).

- Project leader: Margareta Wahlström (Margareta.Wahlstrom@vtt.fi).

- Participating organisations: Lappeenranta University of Technology (FI), Luleå University of Technology (SE), SINTEF, (NO), Norwegian University of Science and Technology (NO), íSOR Iceland Geosurvey (IS), VEOLIA Water Technologies (DK), Outotec Oyj (FI), ÅF Consult Ltd (FI), FOM Kevitsa Mining Oy (FI), Dragon Mining Oy (FI), LKAB Luossavaara Kiirunavaara AB (SE), FinnMin Finnish Association of Extractive Resources Industry $(\mathrm{Fl})$, SveMin Swedish Association of Mines, Mineral and Metal Producers (SE).

- NordMin funding: DKK 5.0 M.

Large quantities of water are used in mining processes as a method of transportation and disposal. By the implementation of new technologies, the opportunity is available to improve water management where leachates, process waters and tailings are all treated and/or recycled while produced.

The project has aimed at:

1. Surveying current practices, their economic and environmental impact and resources available for alternative practices.

2. Identification of requirements for recycling and disposal.

3. Identification and evaluation of key technologies for water management and treatment.

4. Reviewing technologies for tailings de watering and treatment.

5. Development and evaluation of aspects of a low water consumption mine concept.

6. Sustainable continuation of Nordic collaboration and research. 
The work has been based on new laboratory testing, previously published results and information shared between project partners and their extensive links to mining technology. The work was divided between collaborators into work packages and tasks hosted by different project partners.

The project has given insights into new low water footprint mine design concepts and created a solid base for development of required technologies. The collaboration has brought a competitive edge to mining research for Nordic collaborators in calls for future research.

WASCIOUS has developed a technology concept for water-conscious mining, and the safe utilisation or disposal of tailings. The cooperation with mines and technology companies is expected to continue.

Figure 5: Partners involved in the WASCIOUS project. Mines involved: Orivesi Mine Finland (Dragon Mining Oy), Kevitsa Mine Finland (Boliden) and LKAB (Sweden). From Wahlström et al. (2016) ${ }^{17}$

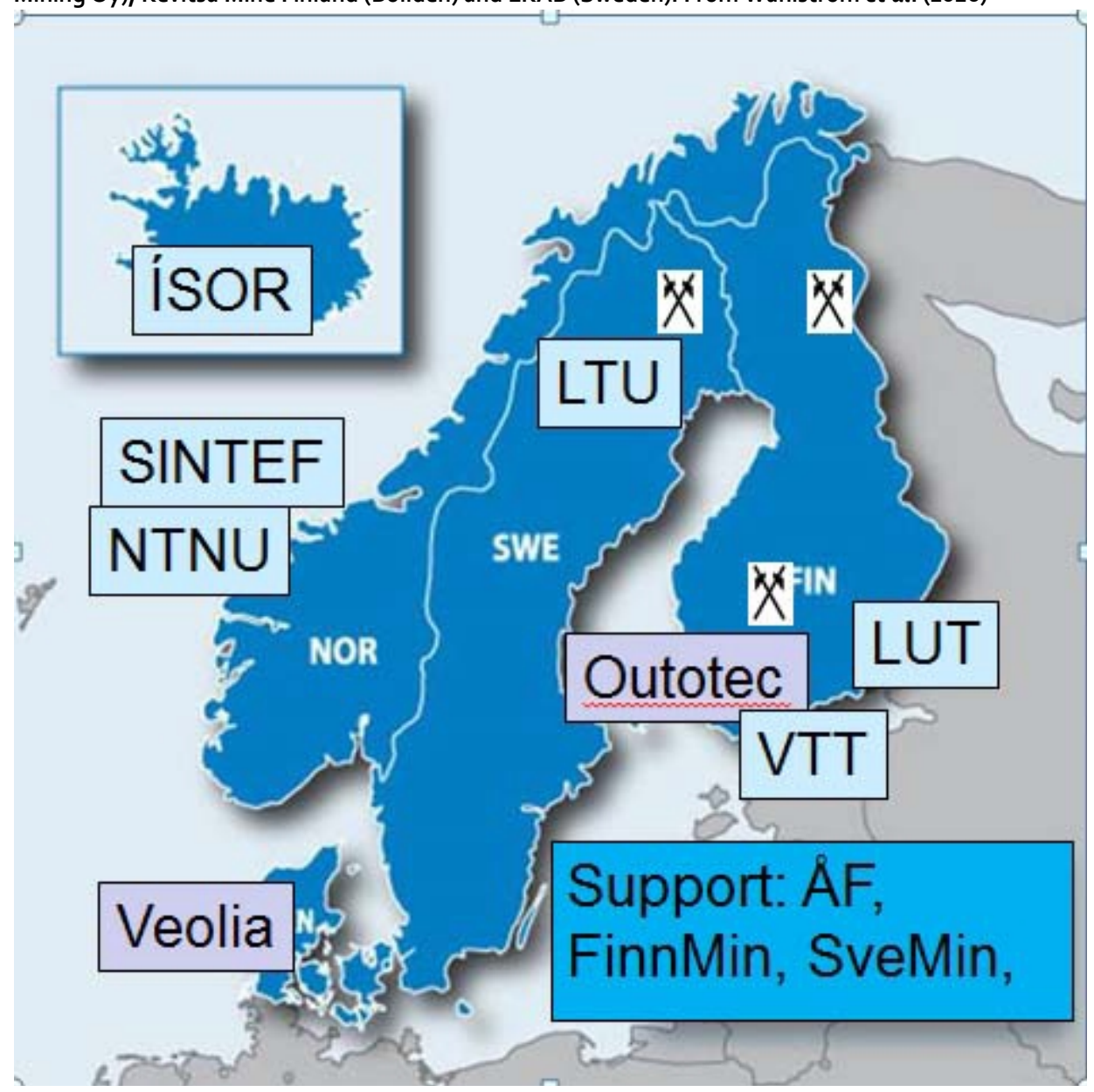

${ }^{17}$ Wahlström et al. (2017). Water Conscious Mining (WASCIOUS).TN2017:525, 195 pp. 


\section{Conclusions}

A comprehensive final report ${ }^{18}$ is available from the project leader Margareta Wahlström VTT upon request. The conclusion from the final report can be found below. Publications from the project are listed at the end of this final NordMin report.

The main focus in the project was on the development of technologies for mine water treatment. However, the treatment of tailings is also an important part of waterconscious mining concepts. In this project, the management of tailings was only addressed to a limited extent without any experimental testing.

Based on a review of current requirements in mine water permits and data on the current discharge levels in the Nordic mines, the project group decided to focus in this project on the removal of sulphate, specific metals ( $\mathrm{Cu}, \mathrm{Ni}, \mathrm{Zn}$ ), and also, to a limited extent, on the removal of nitrogen compounds). The starting point was also a state-ofthe-art review of commercially available technologies or proven technologies tested, at least, with pilot studies.

In the project, several potential technologies for sulphate and metal removal from wastewater were tested and further developed for the Nordic conditions and the requirements by the participating research organisations and the companies. The technological readiness level (TRL) of the selected technologies varied from research based to proven technologies. In order to enable comparisons of the performance of different technologies tested and developed by the research organisations, part of the experimental works were conducted with synthetic mine water samples prepared according to a standardised recipe. However, it needs to be emphasised that test runs with real mine water in conditions as close as possible to reality are crucial for a reliable evaluation/assessment of the applicability of the technology. The pilot test runs with proven technologies were performed with real mine water and partially real conditions.

In the Nordic mines, the requirements on acceptable emissions can be regarded as low for several substances. Therefore, the pollutant levels were rather low both in the synthetic and real mine water samples, which means that the removal efficiency cannot solely be evaluated based on removal percentages. A number of combinations of technologies were performed. The following technologies were studied in the project: electrocoagulation, biosorption, chemical precipitation, membrane processes, eutectic freeze crystallisation, adsorption and biological processes for nitrogen removal.

It can be concluded from the performed experimental tests that ettringite precipitation, and especially nanofiltration membranes, are currently the most efficient technologies for sulphate removal from the mine waters. Achieved removal efficiencies of sulphate were also generally successful with electrocoagulation and ultrafiltration membranes. The advantage of electrocoagulation is that no chemicals are needed, and thus it can be seen as a potential new technology for treating mine waters. Eutectic Freeze Crystallization appears to be particularly suited for waters with high salt concentrations. Biosorption was not found a suitable method for sulphate removal.

${ }^{18}$ Wahlström et al. (2017). Water Conscious Mining (WASCIOUS). TN2017:525, 195 pp. 
Good results were achieved for metals removal with ettringite precipitation, electrocoagulation and with eutectic freeze crystallisation after 2-3 washing times with ice. With membranes, around, $50 \%$ of the metals were removed from the treated waters. Biosorption was not applicable for metal removal in this context.

Further work is still needed, particularly with electrocoagulation, freeze crystallisation and membranes. Moreover, the applicability of different combinations of studied technologies should be studied.

Water-conscious mining means that all challenges - water treatment for recycling, tailings dewatering, waste rock storage and process water treatment - must be addressed. The primary focus in this report was on water treatment technologies for certain key substances. The work also included a literature study on technologies for removal of water from tailings and a LCA study on dewatering technologies in a selected scenario, although this did not include any experimental work.

There are proven water treatment technologies available for the removal of key substances. The choice of the suitable technology depends on the water quality and especially on the level of pollutants to be removed. The possible use of the treated water as process water, or alternatively discharge to the receiving water body, determines the goals of water treatment. Moreover, frequently a combination of technologies would be needed, and, in addition, the artic conditions influence the selection of the treatment concept (e.g. in biological processes). However, there is still a need for new cost-efficient technological concepts for the treatment of waters to achieve low residual concentrations.

The possibilities for water recycling in a mine are heavily dependent on the ore type and thus the dissolving substances. In some cases, water recycling without treatment may lead to accumulation of unwanted substances and potentially also, for instance, gypsum precipitation in pipelines and equipment.

The simulation of different processing and technology alternatives provides important information on both water flows and rough operational costs for comparison. For feasibility studies, information on CAPEX and OPEX is also crucial. In addition to the analysis on the feasibility, an evaluation of the water footprint based on lifecycle principles would offer an overview on sustainability of the water treatment concept.

In this project, the simulation of water treatment and recycling was performed at two mines and gave information on the impact of treated and recycled water in the full water balance, the removal of species, and also the operational costs. It should be noted that the simulation or calculation results shown in this report have been produced merely to illustrate the methodology. The simulation of the mine water flow and the quality in case of water recycling and use of various set of treatment technologies sets still requires validation of actual concentrations and flows. Moreover, the LCA approach used in the hypothetical case study on removal of water in tailings management suggests the need for further discussion on the used boundary conditions in the calculations and the assumptions. 


\subsubsection{Sustainability Criteria for the Nordic Extractive Industry (commissioned)}

- Contractor: Luleå University of Technology (LTU).

- Project leader: Helena Ranängen (helena.ranangen@Itu.se).

- NordMin funding: DKK $1.1 \mathrm{M}$.

Following the funding of the feasibility pre-study (NCM TemaNord 2015:542 - Project leader: Petter Hojem, NordMin funding DKK 360,000 ) on identification of sustainability criteria for the Nordic Mining industry "Mining in the Nordic Countries - A comparative review of legislation and taxation", the Steering Committee commissioned the Management to lead a research project aiming at the development of common sustainability criteria (ethical guidelines/principles) that can be adopted by the Nordic Extractive Industry.

The mining industry has a major impact on society, both from an economic, environmental and social perspective and due to the vast number of criteria involved. Which criteria should be given priority depends on where the mining operations take place. The purpose is to examine the Nordic mining industry's sustainability practice and to develop a guideline for its sustainability efforts. The research methods used in the study include a literature review, a content analysis of sustainability reports, a review of existing sustainability initiatives, guidelines and tools, a stakeholder survey and interviews with mining company officials. For the development of the criteria, a wide range of stakeholders was involved (industry, policy-makers, authorities, NGOs and others, on local, regional and national levels).

Based on the findings, a sustainability criteria guideline was developed in the fields of corporate governance, fair operating practices, economic aspects, human rights, labour practices, society and the environment. The guideline can be found in the NCM TemaNord publication TN2016:560 "A path towards sustainability for the Nordic mining industry". ${ }^{19}$

\subsection{Workshops}

NordMin organised 2-3 workshops per year, eight in total and at least one workshop/Nordic country. The working model was one-/two-day workshops within a predefined core theme. Invited speakers, representing academia, research institutes, NGOs, public authorities and industry, collectively described the relevant challenges we face in a particular core theme and put forward directions for possible solutions. The aim of the workshops was the stimulation of project ideas and discussions on forming preparatory projects to develop NordMin leverage; therefore, every workshop entailed the launch of a call for preparatory project proposals.

${ }^{19}$ Ranängen et al. (2016). A path towards sustainability for the Nordic mining industry. TN2016:560 $96 \mathrm{pp}$. 
The workshops were managed by the country coordinators and/or by the NordMin Management, on decisions made by the NordMin Steering Committee after recommendation from the Management, supported by the Advisory Board.

Eight workshops were organised during the NordMin project period. Each is briefly described below.

\subsubsection{Funding possibilities for Nordic cooperation in the Mining industry}

- Date: 4 September 2014.

- Place: Copenhagen.

- Organisers: NordMin Management, Pär Weihed and Betty Christakopoulou.

- Organising country: Sweden.

- Number of participants: 26.

- NordMin funding: - (costs covered by NordMin management budget).

The NordMin management organised the first NordMin workshop "Funding Possibilities for Nordic Cooperation in the Mining Industry". The 26 participants represented research institutes, universities, industry, public authorities and funding agencies. The scope of the workshop was to present different funding possibilities in the sector.

Representatives from the EU, Interreg Northern Periphery, and Nordic Innovation presented different funding possibilities (Horizon2020, Interreg Northern Periphery \& Arctic Program, Mining Innovation).

At the workshop, a call for Preparatory Project Proposals on the Sustainable Raw Materials Sector was launched. Responding to this call, the preparatory project "Spectroscopic quantification of critical minerals and applications for exploration and mining" received funding from NordMin DKK 107,612 (see preparatory projects below).

\subsubsection{Nordic Aggregates and Stones - Information and Collaboration}

- Date: 18-19 November 2014.

- Place: Trondheim.

- Organisers: The Geological Survey of Norway.

- Organising country: Norway.

- Number of participants: >6o.

- NordMin funding: DKK 240,000.

The Geological Survey of Norway (NGU) was granted a financial contribution from NordMin for the implementation of the workshop "Nordic Aggregates and Stones Information and Collaboration". More than 60 participants from all Nordic countries attended. Representatives from the industry (both aggregates and natural stone), municipalities and research institutes participated. Present and future projects were presented from all countries. Common challenges and possibilities were identified in 
group discussions. In addition to common project ideas, the meeting and exchange of ideas and experiences between different nations and working environments also turned out to be fruitful in themselves. Accordingly, there is also a desire among the participants to establish bi-annual natural construction materials meeting points. At the workshop, a call for Preparatory Project Proposals on Natural Construction Materials Sector was announced.

Responding to this call, the preparatory project "Sustainable Stone Industry in the Northern communities" received funding from NordMin DKK 200,000 (see preparatory projects below).

\subsubsection{On- and Offshore Exploration and Prospecting in extreme Nordic} environments: challenges and benefits of finding exploitable raw materials

- Date: 23-24 March 2015.

- Place: Reykjavík.

- Organisers: The National Energy Authority, Iceland GeoSurvey, Faculty of Earth Sciences, University of Iceland.

- Organising country: Iceland.

- Number of participants: 63 .

- NordMin funding: DKK 350,000.

The third NordMin Workshop was held in Reykjavík, Iceland 23-24 March, 2015. The title of the workshop was "On- and Offshore Exploration and Prospecting in Extreme Nordic Environments: Challenges and Benefits of Finding Exploitable Raw Materials". The National Energy Authority (Orkustofnun) was responsible for the workshop, with assistance from Iceland GeoSurvey (ÍSOR) and the Faculty of Earth Sciences, University of Iceland.

The workshop was attended by 63 participants from all the five Nordic countries, including Greenland and the Faroe Islands, and furthermore representatives from the United Kingdom and Germany. The participants came from research institutes, universities, industry, administration agencies and ministries.

A one-day field excursion was undertaken prior to the workshop focusing on the Thormodsdalur gold prospect, geothermal power plants and the geological phenomena of the Reykjanes volcanic zone. The following two-day workshop emphasised on- and offshore exploration and prospecting in extreme Nordic environments. The first day primarily involved offshore exploration with lectures covering sulfide deposition within geothermal systems and black smokers on the MidAtlantic Ridge and metal deposition in the Baltic Sea. On the second day, the focus was on onshore exploration in Fennoscandia, Iceland and Greenland. The main purpose of the workshop was networking by the Nordic participants and the formation of research groups that could pursue further research project applications to relevant grant bodies. 
At the workshop, a call for Preparatory Project Proposals on On- and Offshore Exploration was announced. Two workgroups were established during the workshop to define two pre-proposals on research and innovation projects. Both of these received grants from NordMin in order to work on full applications to appropriate grant bodies, as following:

"Modern and ancient VMS-forming hydrothermal systems", coordinated by the Iceland GeoSurvey (ÍSOR), along with nine research institutes and universities from Norway, Sweden, Denmark-Greenland, Iceland, Finland and Faroe Islands. Funding from NordMin DKK 200,000 (see preparatory projects below).

"Assessment of undiscovered mineral resources in the Nordic countries and Greenland" coordinated by the Geological Survey of Finland (GTK), along with geological surveys in Denmark-Greenland, Norway, Sweden and Iceland. Funding from NordMin DKK 200,000 (see preparatory projects below).

\subsubsection{Nordic Underground Mining Method (NUMM)}

- Date: 4 May 2015.

- Place: Stockholm.

- Organisers: The Norwegian University of Science and Technology, Department of Geology and Mineral Resources Engineering.

- Organising country: Norway.

- Number of participants: 15.

- NordMin funding: DKK 200,000.

The Norwegian University of Science and Technology, Department of Geology and Mineral Resources Engineering, was granted a financial contribution from NordMin for the implementation of the workshop "Nordic Underground Mining Method" (NUMM). The workshop was organised in co-operation with Luleå University of Technology and it was held at Arlanda Airport, Sweden, on May 4, 2015.

The workshop was arranged with 15 participants from three Nordic countries. Mining companies, tunnelling contractors, equipment suppliers and universities in Norway, Sweden and Finland were represented.

Input to the workshop discussions came from the results from an indicative prestudy based on a limited number of interviews among mining- and tunnelling companies in Norway and Sweden. The findings were presented at the workshop.

The hypothesis was that there is a significant difference in performance between Nordic tunnelling- and mining companies with respect to efficiency and costs. There might thus be questions as to whether there also may be a difference in safety, working environment, environmental impact, etc.

The overall objective of NUMM was "to integrate cost-efficient and productive practices from the tunnelling industry with the well proven traditions from large international mining companies, and together with novel technical solutions describe 
an innovative and sustainable Nordic Underground Mining Method (NUMM) adapted to our unique Nordic conditions."

The purpose of this workshop was to:

- Investigate whether there is still sufficient potential and interest to launch a full research project as proposed in the original NUMM-application to NordMin.

- Refine the working hypothesis, and thus the scope, of the research project based on discussions of the findings from the indicative pre-studies.

- Identify potential partners and funding mechanisms.

The findings from an interview-based pre-study were presented and verified by the participants. This study showed that a majority of the respondents believe that the tunnelling contractors are more efficient and achieve higher quality in development drifting than the mining companies themselves. The study also indicates that there is no perceived difference in health and safety performance. The following project ideas meriting further development were identified:

1. A quantitative, comparative study of the performance in mining and tunnelling companies.

2. Short-interval control and individual performance in mining.

3. A Lean study of mining operations.

\subsubsection{Mining and Society in the Arctic}

- Date: 6-7 June 2015.

- Place: Sisimiut.

- Organisers: Greenland School of Minerals \& Petroleum.

- Organising country: Greenland.

- Number of participants: 85 .

- NordMin funding: DKK 175,000.

Greenland School of Minerals \& Petroleum was granted a financial contribution from NordMin for the implementation of the workshop "Mining and Society in the Arctic".

The workshop was arranged with 85 participants from NordMin members, the Nordic countries, Canada and the USA. Students and teachers from Greenland School of Minerals \& Petroleum and DTU ARTEK. Representatives from Qeqqata Municipality and the Greenlandic Minister of Industry, Labour and Trade \& Foreign Affairs, Vittus Qujaukitsoq, were represented.

The scope of the workshop was to meet colleagues within mining from all Arctic countries, Canada, Russia, the USA, Norway, Sweden, Finland, Iceland and Greenland/Denmark and also to offer the opportunity to expand networks and obtain further knowledge regarding mining and society within the Arctic Circle. 
At the workshop, a call for Preparatory Project Proposals on Mining and Society in the Arctic was announced. Responding to this call, the preparatory project "Mining, quarrying and tourism development" received funding from NordMin DKK 175, 246 (see preparatory projects below).

\subsubsection{Mineral waste - disposal or value creation? Need for research and innovation}

- Date: 17 March 2016.

- Place: Mo i Rana.

- Organisers: SINTEF.

- Organising country: Norway.

- Number of participants: 55 .

- NordMin funding: DKK 350,000.

SINTEF was granted a financial contribution from NordMin for the implementation of the workshop "Mineral waste - disposal or value creation? Need for research and innovation".

The workshop was held in the town of Mo i Rana, North Norway, and it was planned and executed as a combined event with the 2016 GeoNor conference.

The purpose of the workshop has been to gather relevant institutions, academia, companies and other interested parties to discuss the issues of mineral waste and to prepare for future research activity in this area. The workshop was organised with introductory talks and followed up with group discussions and presentations. As background input, the organisers presented some questions that the participants could discuss, or, alternatively, they could find other areas of interest by themselves:

1. Identify sources for project financing.

2. Discuss different themes that can be of interest.

3. Discuss possible networks and possible partners.

4. Discuss research areas.

5. Discuss disposal practices.

A total of 55 participants from all the Nordic countries were involved in the workshop and gave valuable input in discussing the workshop's theme. The workshop was introduced through four presentations, from Norway, Iceland, Denmark and Finland. From these four countries national and regional challenges were presented and discussed, in order to provide some background for group discussions.

The participants were then organised into four groups, giving their feedback in plenum. Many valuable and interesting thoughts were shared, and we expect that several institutions will follow up the workshop outcomes by developing project ideas and proposals. Among several good ideas from the groups, the idea of a Nordic 
Information Platform was presented, along with projects related to Sustainability in Mineral production, the need for social dialogue and environmental guidelines. One group highlighted the importance of developing a Nordic database of mineral waste and another pointed out the need for a research centre focused on sustainable mineral development.

At the workshop, a call for Preparatory Project Proposals on Mineral Waste was launched. Responding to this call, five preparatory projects were funded:

- "Biochar, mine wastes and rest materials from other industries as a tool for mineral waste and landscaping solutions". Funding from NordMin:

max. DKK 200,000 (see preparatory projects below).

- (USEFULWASTE) "New recovery technologies to extract market products from mine waste water and tailing and add value to tailing by transforming in a geopolymer or inert material to the environment". Funding from NordMin: max. DKK 200,000 (see preparatory projects below).

- "Waste to Mine: From Pollution Source to Georesource". Funding from NordMin: max. DKK 200,000 (see preparatory projects below).

- "Extraction of resources from waste streams in the Nordic region". Funding from NordMin: max. DKK 150,000 (see preparatory projects below).

- (NEXT) "Next generation of EXtraction \& Separation Technologies". Funding from NordMin: max. DKK 200,000 (see preparatory projects below).

\subsubsection{How to go further in Nordic collaboration in Mining Research and Education}

- Date: 19-20 October 2016.

- Place: Helsinki.

- Organisers: VTT.

- Organising country: Finland.

- Number of participants: 80.

- NordMin funding: DKK 228,606.

The VTT was granted a financial contribution from NordMin for the implementation of the workshop "How to go further in Nordic collaboration in the mining research and education".

The workshop was arranged with 80 participants from five Nordic countries: Denmark, Finland, Iceland, Norway and Sweden. Representatives from the EIT RawMaterials were represented.

The aim of the workshop was to present and review the experiences and results gained from recent Nordic collaboration projects, which covered different stages of the mining value chain. In a round-table discussion, representatives of the mining industry will meet financiers to discuss the common funding possibilities for satisfying the 
Nordic learning and research needs. Moreover, a special topic was how to enhance education at different levels, especially the lifelong learning during professional careers in the mineral sector. The target is to shape proposals for enhancing education, which EIT RawMaterials has the possibility to fund. The workshop was opened by Mr. Petri Peltonen from the Finnish Ministry of Economic Affairs and Employment (MEAE) who stressed the importance of Nordic collaboration in the mining field.

The focus of the morning session, chaired by Ms. Riikka Aaltonen from MEAE, was on the six projects funded by NordMin. The project coordinators presented the core content and benefits of their project, along with ideas for continuing to build knowledge and further add value of Nordic projects. These projects covered many different aspects related to mining and the presentations engaged the audience in discussions. The NordMin manager, Prof. Par Weihed, also briefly presented the NordMin focus areas and networking activities. The morning session served as a good background for the afternoon discussions on possibilities for future funding.

The afternoon session started with a round-table discussion with participants from several funding agencies and industry and was moderated by Mr. Harry Sandström from the Geological Survey of Finland. The key topics for discussion were on identification of industry and societal needs and potential research solutions. The round-table discussion was interactive and involved the audience. Several participants stressed the importance of mining in Nordic countries due to high standards of clean technologies and safety aspects. During the discussion, the need for collaboration and networking was emphasised. Following the round-table discussion, workshop participants had the opportunity to have face-to-face meetings with the various research financing organisations.

The last part of the afternoon was dedicated to Nordic collaboration in education. Dr Karen Hanghöj gave a presentation on EIT raw material activities and mission and also the KIC funding possibilities for education. Following this, the participants continued discussions in two workgroups: Lifelong learning; and $\mathrm{PhD}$ and Masters education. In these group discussions, ideas for future projects were discussed and the conclusions were presented to the entire audience.

\subsubsection{Nordic 3 Deological modelling}

- Date: 8-10 November 2016.

- Place: Trondheim.

- Organisers: The Geological Survey of Norway.

- Organising country: Norway.

- Number of participants: 34 .

- NordMin funding: DKK 92,000.

The Geological Survey of Norway was granted a financial contribution from NordMin for the implementation of the workshop "NordMin Nordic 3D geological modelling workshop". 
The workshop was arranged with 34 participants from five Nordic countries: Finland, Sweden, Denmark, Iceland, and Norway.

Knowledge of the subsurface geology in $3 \mathrm{D}$ space is essential for a wide range of geoscientific applications and the demand for reliable ${ }_{3} D$ models is rising. Despite the increasing need for reliable 3D models, comparatively few people or small teams are involved in $3 \mathrm{D}$ geological modelling in the Nordic countries. The workshop aimed to provide a platform to meet and bring together geologists involved in diverse projects to get to know colleagues working on similar or different questions, in order to discuss and exchange experiences and, in this way, to avoid isolation and create a community of knowledge and mutual support.

A total of 34 participants from Finland, Sweden, Denmark, Iceland, and Norway presented talks and posters and participated in intense discussions. Topics were categorised into three main themes:

1. 3D modelling of geology and ore deposits.

2. 3D modelling in applied geology and geotechnical tasks.

3. Methodology, theoretical considerations, and application of new technologies.

The meeting started with presentations by two keynote speakers from Australia and Germany. On the final day, the workshop aimed to discuss current hot topics and future directions in 3D geological modelling, such as the integration of geophysical and geological data, uncertainty estimation, evaluation and presentation, ways of reporting of the modelling process and storage of models and metadata, presentation of models and their uncertainties to other scientists and non-scientific stakeholders.

The workshop was successful in respect to both scientific and social benefit, and received very positive feedback from all participants, who expressed an interest of continuing such meetings, for example every two years. A Raw Materials Co-location Centre of the European Institute of Innovation and Technology (EIT) is installed in Luleå and the associated Knowledge and Innovation Community (KIC) may serve as a framework for future workshops.

\subsection{Preparatory projects}

Preparatory projects were based on results from workshops and the aim was to develop NordMin leverage within the core themes. NordMin covered the costs for establishing a partnership (consortium) in order to submit a proposal to an external funding body (national, Nordic, EU or international), up to a maximum of 200,000 DKK/preparatory project.

Preparatory project calls opened for four weeks at every NordMin workshop, i.e. 2-3 times/year. Each call was based on the theme chosen for the relevant NordMin workshop. The preparatory project was to be linked to a coming external call and participation from 
at least three Nordic countries was mandatory. Decisions on funding were made by the NordMin Steering Committee.

NordMin launched six calls for preparatory project proposals and funded eleven preparatory projects in total. Each preparatory project is described below:

\subsection{1 "NordMin Center of Excellence" (NordMinCoE)}

- Coordinator: SINTEF.

- Partners: SINTEF, Norwegian University of Science and Technology (NTNU), The Geological Survey of Denmark and Greenland (GEUS), Luleå University of Technology (LTU), Iceland GeoSurvey (ÍSOR), Oulu University, University of Reykjavik, USGS (USA), Outotec, University of Waterloo (Canada).

- NordMin funding: DKK 200,000.

SINTEF coordinated the preparation of a joint application aiming to establish a NordMin Excellence Centre in mining research from 2016 onwards. The project proposal called "NordMin Center of Excellence in Sustainable Mining \& Minerals" (NordMin CoE) was submitted to NordForsk-program: Joint Nordic Initiative on Arctic Research, "Responsible Development of the Arctic: Opportunities and Challenges Pathways to Action".

In order to avoid exploitation, the Arctic region must seek to maximise the positive sides of mining, such as employment, spin-off effects, spillover effects and tax revenues. Negative impacts on local communities and the environment from mining must be minimised. To achieve these two objectives, the mining industry, from exploration to production and waste management, must be efficient, effective and sustainable. In addition, positive ripple effects from mining to other industrial sectors in the Arctic must be optimised. This Centre of Excellence ( $\mathrm{CoE}$ ) will not only create knowledge about these issues, but also implement many of them in the Arctic during the project period.

- This CoE aimed to educate both mining companies, regulating authorities and the general public on how to evaluate mining projects and what is the state of the art with respect to mining methods.

- This CoE should benchmark the performance in mining and tunnelling companies in order to quantify the effects of the equipment strategies and the workforce organisation and management.

- This CoE would use a combination of standard mineral potential assessment, statistical potential mapping and economic validation to outline new potential areas for mineral exploration, and to assess the mineral potential between already known metallogenic provinces for long-term raw material supply. Direct online geochemical and geophysical analysis during diamond drilling should be developed further in order to make better use of the expensive and timeconsuming drilling process. That could revolutionise the expensive process of 
defining an ore body in a mineral deposit. This CoE would contribute to such a technical development.

The major potential long-term environmental effect of mining is the formation of acid rock drainage (ARD) in sulphide-bearing mine waste, which can last for hundreds of years in a waste deposit. The global production of mine waste is more than 20,000 million tons of solid waste each year. Within Norrbotten (the northernmost county in Sweden) alone, it is likely that, within 10 years, the annual production of tailings will be 120 million ton ( 85 million ton sulphide-bearing and 35 from iron mining), and as least as much waste rock. Tailings management is thus very important. To find best practices and technologies suitable for the Arctic, this CoE would analyse paste technology for sustainable mine tailings management and submarine tailings disposal.

There must be both a good human environment and physical environment for research and learning processes to gain a sufficient stock of knowledge to meet the objectives for this Centre of Excellence. Both from theory and empirical data, we know that industrial clusters increase productivity, stimulate and enable innovations and facilitate commercialisation and new business formation.

This CoE would be the core unit of a research and innovation cluster. The cluster would consist of all the stakeholders in the mining sector, including mining companies, current and potential suppliers, distributors, teaching institutions, research institutions, regional and local authorities, and NGOs. The CoE would be an enabler for creating a sustainable mining cluster in the Arctic, and thereby contribute to high ripple effects from mining to other sectors in the Arctic.

Research by this CoE would create knowledge about which regulations, sanctions, stimulations and incentives that should be in place to achieve sustainable development in the Arctic regarding mining. Regulations may be both formal (e.g. laws and written rules) and informal (e.g. code of conduct and code of practice). In particular, the latter depends on culture and mode of living, and consists of an environment for entrepreneurship, innovation and culture for industrial activity. This informal framework for business development would be stimulated and encouraged by this $\mathrm{CoE}$ through its mining cluster.

Information from the mining sector by the CoE about what should be in place to receive maximum economic ripple effects to other sectors in the Arctic would be used for policy measures with regard to improvements and adjustments of education, training, infrastructure, investment climate and of forces of attraction of labour.

After the initial period of five years, the CoE would seek to sustain itself through annual fees paid by permanent members, including research institutions, NGOs and private companies. The ambition would be to use the majority of the fees on new research projects to ensure the continuous improvement of a high value added and sustainable mining sector in the Arctic.

To ensure an international impact, this $\mathrm{CoE}$ should consist of members from all the Nordic countries and of associate members from Canada and Alaska. These members were recruited from well-known universities and research institutes. 
Results

Despite the positive feedback, the project proposal was not selected for funding from NordForsk.

\subsection{2 "Spectroscopic quantification of critical minerals and applications for} exploration and mining"

- Coordinator: University of Oulu, Oulu Mining School.

- Partners: Oulu Mining School, University of Oulu, University of Copenhagen, University of Oslo, Swedish Museum of Natural History, Geological Survey of Finland.

- $\quad$ NordMin funding: DKK 107,612.

The preparatory project was targeted at the calls for the Mineral Resources and Material Substitution Research Programme, Academy of Finland (closed 3oth September 2014 and 12th February 2015) and EU Horizon 2020 Programme: Growing a Low Carbon, Resource Efficient Economy with a Sustainable Supply of Raw Materials (closed 21st April 2015).

The project addressed the production shortfall of critical metals and environmental challenges in the mining sector by the use of the novel combination of optical mineral characterisation tools connected to the Science Based Calibration (SBC) method. The envisaged results would have allowed near real-time online mineralogical analysis, thus enabling the adjustment of the process in real time. This should be an essential tool for mining companies to optimise their mining processes from the exploration and drilling phase to the end product quality, and to significantly reduce the amount of chemicals, consumables and waste during the mining activities as well as improve their profitability.

In addition, this new method could also provide the essential mineralogical information during the drilling process and could help to avoid transportation of ground side rocks and therefore enhance the substantial reduction to the energy consumption of transportation, crushing and grinding stages. The need for the quantitative analysis is increasing, since the ores are to be poorer and more complicated in their mineralogy and content of valuables. Spectroscopic quantification enables, for instance, fast threedimensional modelling of ore bodies.

\section{Results}

The Academy call had two stages and the project passed the first stage in December 2014. Unfortunately, the project was dismissed for the first standby position in the final stage, June 2015. As the consortium had difficulties in getting partners outside Scandinavian countries, they did not submit an application to Horizon 2020. It also appeared that the economic situation in mining industry was not suitable for devoting new innovations. 


\subsection{3 "Sustainable Stone Industry in the Northern communities"}

- Coordinator: Geological Survey of Finland (GTK).

- Partners: The Geological Survey of Norway (NGU) Lead Applicant, Natural Environment Research Council, as represented by its component institute, the British Geological Survey (NERC/BGS), The Geological Survey of Finland (GTK) SINTEF Building and Infrastructure (Norway), The Geological Survey of Denmark and Greenland (GEUS), The Swedish Cement and Concrete Research Institute $(\mathrm{CBI})$, Foundation for the Museums in Sogn og Fjordane (MISF) (Norway).

- Associated partners: Swedish Stone Industries Federation (SFI), Sør-Trøndelag County Authority (Norway), National Board of Antiquities (Finland) Finnish Natural Stone Association (Finland).

- NordMin funding: DKK 200,000.

It is witnessed that the Nordic stone industry, even having strong historical roots, has been declining due to changes in the labour market and the widespread adoption of cheaper imported building materials rather than locally sourced ones, ignoring its important contribution to the character of the built environment in many communities and deleting the memory that the stone industries have created valuable and internationally recognised artisanal traditions for extracting, processing and using the material.

This results in: (i) the creation of abandoned quarry landscapes, with widespread loss of associated jobs, skills and knowledge; (ii) an ongoing dilution of cultural heritage as quarrying-related traditions disappear and stone buildings are repaired (or constructed) with imported stone and other materials; (iii) a growing cost to the environment as building materials are imported from ever-greater distances (e.g. China, Brazil, India).

The main problem that this project intends to address is a lack of awareness amongst stakeholders of key issues relating to the history of natural stone extraction and use in remote communities, the gradual dilution and loss of income, knowledge, skills and cultural heritage that has accompanied the move towards other building materials and imported stone, and the significant economic, social, cultural and environmental benefits that could result in remote communities if stone extraction was to resume, or if alternative uses were found for disused quarries. This problem is common to all parts of the NPA area and HeriStone aims to turn this problem into an opportunity by presenting knowledge and developing tools that can inspire and aid stakeholders in finding new solutions.

The project aims to build a platform that contains all the information, guidance and tools that local authorities, general public, SMEs and other stakeholders need to effectively and sustainably manage both the legacy and rejuvenation of local building stone industries and associated cultural heritage in the Nordic territory. 
Results

Under NordMin funding, a project: "HeriStone - Sustainable Governance of Northern Stone Heritage", was planned and applied to the third call of the Northern periphery and Arctic programme under Axes 4 in November 2015.

\subsection{4 "Assessment of undiscovered mineral resources in the Nordic countries and Greenland"}

- Coordinator: Geological Survey of Finland (GTK).

- Partners: Geological Survey of Denmark and Greenland (GEUS) - core partner, coordinator, Geological Survey of Finland (GTK) - core partner, Geological Survey of Sweden (SGU) - core partner, Geological Survey of Norway (NGU) - task partner, Iceland GeoSurvey (ÍSOR) - task partner.

- Additional partners that joined the consortium: University of Oulu, Oulu Mining School (OMS) - core partner, DMT GmbH \& Co. KG (DMT) - core partner, The Norwegian University of Science and Technology (NTNU) - task partner, U.S. Geological Survey (USGS) - task partner, Scandinavian Highlands (SHH) - task partner, LTU Business AB (LTUB) - task partner.

- NordMin funding: DKK 200,000.

Information on raw materials and their distribution is vital for the successful management and planning of land use; it directs mineral exploration, and it is important for sustainable natural resources exploitation. Most of the published quantitative assessments of undiscovered mineral resources have been carried out using the threepart assessment method, which was developed by the U.S. Geological Survey (USGS) in the mid-1970s. The method itself has not changed much since its creation, although the software used to perform the assessments has evolved through at least three generations. Hence, due to an increasing use of the method and software globally, there is a need for an upgrade and enhancement of both the assessment methodology and the software tools.

\section{Results}

This preparatory project created a proposal for an upscaling project called "Mineral Resources Assessment Platform (MAP)", which was submitted to the EIT Raw Materials 2016 KAVA call. The MAP project will produce a modernised assessment process and an integrated software system that utilises the process. The developed process integrates predictive mineral potential mapping components to the three-part assessment method. The open access, freely and publically available software will provide a flexible, wizard-guided environment to carry out fully documented, modern assessments. The modular structure of the software will enable further enhancements of both the assessment process and software in the future. The testing phase of the MAP project will produce the first systematic and comparable assessments of undiscovered mineral resources in the Nordic countries and Greenland, as well as on the Arctic sea floor. 
The final goal of the MAP project is to promote natural resource management and land use planning, to direct targeted mineral exploration according to the principles of sustainable development, to attract mineral exploration companies and create conditions for the continuing development of the mineral sector by homogenising the data in the Nordic countries, and to strengthen and increase the undiscovered mineral resource assessment know-how and skills in the participating organisations.

\subsection{5 "Modern and ancient VMS-forming hydrothermal systems"}

- Coordinator: Iceland GeoSurvey (ÍSOR).

- Partners: Iceland GeoSurvey (ÍSOR), The Geological Survey of Norway (NGU), Geological Survey of Sweden (SGU), The Geological Survey of Denmark and Green land (GEUS), University of Bergen (UiB), Norwegian University of Science and Technology (NTNU), SINTEF, University of Iceland, Geological Survey of Finland (GTK), Jarðfeingi - Faroese Earth and Energy Directorate.

- NordMin funding: max. DKK 100,000.

VMS (volcanic massive sulphide) deposits are, and have been, a key source for many important metals, such as copper, zinc, gold and silver. Almost all VMS mining activities have been on land, and are related to onshore deposits, or represent old oceanic vent systems, abducted onto continents during plate tectonic events. As the need for these resources raises, interest in mining active or young systems on the sea floor is likely to increase. With this in mind, it is paramount that we build up the knowledge bank for potential offshore VMS deposits. Knowledge of the onshore resources, exploited for hundreds of years, will be fundamental to future mining in the deep sea, and conversely, monitoring and studies of the active processes on the sea floor will increase our understanding of onshore resources.

The aim of this project is to develop new sensitive technologies for on- and offshore exploration and environmental monitoring, giving new insight into deposit characteristics and how the deposits are distributed and formed in $2 \mathrm{D}, 3 \mathrm{D}$ and possibly $4 \mathrm{D}$, and to build a bridge between on- and offshore systems by acquiring new knowledge and understanding that benefits both on- and offshore exploration and mining. The main focus is on the ore-forming systems, the hydrothermal mechanisms and the geodynamic systems that drive them.

Mineral exploration for undiscovered VMS deposits needs to be based on characterisation of VMS ore-forming systems. Further knowledge of the metal sources, transportation and deposition within VMS systems is required, along with a better understanding of the preservation potential for VMS deposits, as well as a need of refining the geological, geochemical and geophysical source indicators and vectors that allow effective targeting of VMS ore deposits.

Geodynamic and tectonic setting of VMS deposits is another key issue for discovery of new deposits, both in young or active VMS systems, as well as in the classical onshore VMS deposits. 
Mineral prospectivity mapping (MPM) and mineral resource assessment (MRA) are two predictive modelling processes for deriving information that is essential for strategic planning in mineral exploration and development. MPM, which could be either data- or knowledge driven, aims to model the prospectivity or likelihood of mineral deposit occurrence regardless of size or grade. MRA aims to: (1) outline geologically permissive terrains where certain types of mineral deposits are likely to exist; (2) estimate the amount of metals in geologically permissive terrains and, (3) estimate the number of undiscovered mineral deposits of each type within geologically permissive terrains.

\section{Results}

The $\mathrm{H}_{2020}$ call that the consortium was aiming at changed, precluding their participation, and thus the consortium was not able to submit a project proposal as scheduled.

\subsection{6 "Mining, quarrying and tourism development"}

- Coordinator: Icelandic Tourism Research Centre (ITRC).

- Partners: Icelandic Tourism Research Centre (ITRC), NordGem AB, Aalborg University, department of culture and global studies Iceland GeoSurvey (ÍSOR), Innovation Center Iceland, Kristallen I Lannavaara AB, Breiðdalssetur.

- NordMin funding: DKK 175,246.

In large parts of the Arctic, no mining operations exist, but materials abound on or near the surface in terrains ranging from sea/lakeside to mountains. Exposed lava, ash, secondary minerals, worn rocks and the like are all used for making souvenirs that promote the uniqueness of a region or a country and sold to tourists. This project proposes a focus on how best practises in the field of gemmology can be disseminated and used to create viable business models for tourism entrepreneurs and rock crafts training. The consortium necessary to create opportunities from surface materials is in three parts. One part is focused on understanding the resource and bringing expertise in locating and extracting the resource as well as understanding the qualities of the raw material to be used. The second part of the consortium deals with product development and business incubation, i.e. how both tourism services based on experience design can be developed around the raw materials and how the processing of the raw materials can be developed. The third part of the necessary consortium is knowledge transfer and skills enhancement, whereby expertise in the treating of minerals and tourism business development is brought into contact with nascent operations. All three parts constantly feed into each other transnationally.

Skills enhancement and B2B knowledge transfer are the key focus of the project where, through a transnational consortium knowledge and understanding about the raw material, the development of viable business models and training and product development will be facilitated through cross-national learning exchanges.

Linking minerals and tourism to facilitate regional development is a component of the knowledge transfer and involves scholars of tourism and regional studies who will 
document the synergies and knowledge transfers occurring in the project and map these onto issues of regional development. The cases in their documented form can be disseminated beyond the project's framework in both space and time.

The skills enhancement will be related to tourism through creating educational spaces for tourists to enjoy and experience the practices of gemmology. In terms of mineral processing, skills enhancement will use these same educational spaces for a more focused workshop for visitors from other project partners to learn the skills necessary for their nascent operations in their respective locations.

Part of the destination development role of the project is how mineral sites and their processing facilities can be marketed and promoted, focusing on experiencebased design. The project will focus on the roles and values of landmarks and monuments in that capacity, i.e. how disused (or still in use) mining sites can be attractions and how, through creating unique features, a processing facility can promote itself. Here, artwork from minerals and larger pieces from mines and sites can be creatively put to use to attract people and publicity. Any destination development project needs to understand the role of place in the valuation process of tourism. These landmarks can be used to entice people into the minuscule world of gemmology.

A key outcome is the inception of destination development through idea generation and match-making facilitated by the educational programme and fieldwork developed around this. This local skills enhancement is an outcome of the project, related to tourism through creating educational spaces for students to enjoy and experience the practices of georesources. These same educational spaces will also offer more focused workshops for locals and visitors from, for instance, other project partners' regions to learn the skills necessary for their nascent operations in their respective locations.

\section{Results}

The first fieldwork site to be developed in accordance to this vision is East Iceland in collaboration with Breiðdalssetur who will do the project leading if funding is ensured. The organisation came into the project in April 2016. Breiðdalssetur sent in two applications to NATA on September 13, 2016. The Icelandic Tourism Research Centre sent in an application to NORA on October 3, 2016. If funding is ensured will Breiðdalssetur organise a field class in May 2017 in collaboration with the consortia established and some new partners from Faroe and Greenland.

3.3.7 "Biochar, mine wastes and rest materials from other industries as a tool for mineral waste and landscaping solutions"

- Coordinator: Geological Survey of Finland (GTK).

- Partners: Geological Survey of Finland (GTK), Natural Resources Institute (Luke), Luleå University of Technology (LTU), Greenland Institute of Natural Resources (GINR), Norwegian University for Technology and Natural Sciences (NTNU).

- NordMin funding: max. DKK 200,000. 
In Finland, Sweden, Norway and Denmark, mining and quarrying generates mineral and solidified wastes c. $200 \mathrm{Mton} / \mathrm{yr}$. The volume of waste has grown in recent decades since the demand for minerals and metals has increased and more low-grade ores are mined due to developed processing technologies.

Good mineral waste coverage and landscaping solutions in the northern mining industry do not exist, or they are expensive. New solutions are needed to minimise damage to the environment and for landscaping purposes. The old waste rock piles are heterogeneous and there have not been other requirements for coverage except slope safety. Today, planning and implementation of mine closure are constrained by legislative requirements and a closure plan must be part of the environmental permission application. Currently, coverage must, for instance, prevent access of $\mathrm{O}_{2}$ to sulphide-bearing waste rock to prevent oxidation and acidification.

The aim of the planned project is to test biochar and mine wastes as a component of mineral waste cover material with rest material. The target is to improve cover's long-term durability and stability, prevent erosion, and improve the sustainability of water management, carbon balance and nutrient economy. There is no knowledge about the behaviour of biochar in mineral waste environment and biochar/peat mixture can possibly replace the artificial membrane solutions used in a basal structures. The mining industry produces large amounts of low-sulphide tailings as a residual after the mineral processing. Tailings have the potential to be utilised solely in protective cover or in a mixture as sealing layer. To improve the properties to fulfil the requirement as a sealing layer, it has to be mixed with other materials to lower its hydraulic conductivity.

Biochar can be produced locally, which diminishes the transport and storage costs and opens new possibilities to develop local entrepreneurship. Willow is good raw material for biochar production but nutrient requirements for its cultivation should be investigated. In the northern area, birch might a better alternative than willow. Local biochar production provides potential for a cascade/recycle concept: Compost plant material for the upbringing of biomass raw materials, biomass material for pyrolysis and from pyrolysis plant biochar for the composting facility. Tailings are produced in large quantities by the mining industry and it might be more economical and beneficial to use the waste as a resource rather than treat it as a waste. Materials needed to improve the tailings such as green liquid dredge are produced by the paper mills but also other rest materials from other industry plants might be interesting to test.

This proposed preparatory project includes building the consortium for research and prepares the actual project plan of "Biochar, mine wastes and rest materials from other industries as a tool for mineral waste and landscaping solutions", networking with companies and charting the cleantech business concepts/forms.

\section{Results}

The project proposal, "Charmine - Biochar, mine wastes and rest materials from other industrials as a tool for mineral waste and landscaping solutions" was submitted to the Northern Periphery and Arctic Programme Fourth Call 1.5.-30.9. Objective 4: Increased capacity of remote and sparsely populated communities for sustainable environmental management. 
3.3.8 "New recovery technologies to extract market products from mine waste water and tailing and add value to tailing by transforming in a geopolymer or inert material to the environment" (USEFULWASTE)

- Coordinator: University of Oulu, Oulu mining School.

- Partners: University of Oulu, Norwegian University of Science and Technology, Luleå Technological University, Technical Research Centre of Finland, Universidad Federico Santa Maria, Pontificia Universidad Catolica del Peru.

- NordMin funding: max. DKK 200,000.

The mining industry is a vital component of the global economy and sustainable mineral processing depends on the improvement and understanding of various continuing and resourceful techniques and the searching of sustainable sources of raw material.

The mining activity in its various stages and operations generates a considerable amount of waste (solid and liquid) and contributes directly or indirectly to environmental pollution. Restriction for the disposal of used water to the environment and impact of tailing dam facilities (visual, airborne transportation, leaching) offers the opportunity to look at these as sources of valuable species and a supplement to a sustainable source of metals and minerals required for the industry and society.

The physical-chemical nature of mineral-water interaction is complicated by chemical reactions between species. The sources of water are significantly influenced by the composition of the water supplied (mine water) the recirculation and contact with mineral (recycled water and wastewater), generally increasing the concentration of the constituents of water. This water needs treatment before discharge into the environment and to fulfil strict environmental regulations.

Mining wastewater generally contains inorganic compounds which are the product of natural oxidation and leaching of soluble mineral phases (dissolved species) including cations ( $\mathrm{Cu}, \mathrm{Fe}, \mathrm{Mn}, \mathrm{Zn}, \mathrm{Ca}$, Mg, heavy metals such as $\mathrm{Pb}, \mathrm{Cd}$, As and anions (sulphates, chlorides, nitrate, phosphates, hydroxides, and carbonates), but also suspended solids (metal ion precipitates, mineral particles). These species present an increased accumulation amount due to acidity, chemical waste and sediment in runoff.

There have been attempts of removal and recovery of metal ions from AMD using adsorption material such as lignite and zeolites (low cost sorbent), bio-treatment and fractional precipitation, but there is need for research in desorption methods to selective separated species.

On the other hand, solid waste in the form of tailing is produced because the used ore and concentrates are only a small fraction of the total volume of the mined material. Although metals are at low concentrations, many of these are worth recovering to offset the cost of treatment. The composition of tailings directly depends on the composition of ore and process of mineral extraction. Common minerals and elements found in tailings include arsenic (found in association with gold ores), barite, calcite, fluorite, mercury, sulphur (forms many sulphide compounds/pyrites), cadmium and others. Additionally, old tailing facilities have a higher metal content than new facilities, 
which have small milled particles as technology has improved and were not recovered before because of the relatively high processing cost and technological issues.

The presence of metals and minerals in mining waste has created a market for treatment technologies of both wastewater and tailing. The existing methods of water treatment (adsorption, reverse osmosis, membrane filtration, electrochemical and biological) present the only alternatives to get rid of water pollutants. However, mining companies are searching for ways to turn waste into profit and avoid polluting the environment. For example, tailings may turn out to be the source of valuable resources such as rare earth elements, which are critical components of electronics and difficult and costly to mine. Moreover, components of tailing by themselves can have industrial value if they are refined. Additionally, there is market for selective metal recovery from mine tailing and mining waste water e.g. $\mathrm{Ni}, \mathrm{Co}$, and $\mathrm{Cu}$.

Those species in wastewater and tailing that were considered to be rejected species might have industrial value. For instance, heavy metals such as cadmium have many industrial uses as key components in battery production, pigments, coating, nuclear fission and electroplating. Arsenic is used in agriculture, medicine and alloys. Others, such as manganese, are used in aluminium alloys, iron and steel production, an additive in unleaded gasoline, as a re-agent in organic chemistry, pigments and replacement in some percentage of ordinary Portland cement. The development, demonstration and piloting of new technologies will lead to a more sustainable, selective and low impact solution for mining.

Therefore, one main objective of this project is the extraction of market-grade products such as metals and metal compounds, or refined metals and minerals, including elemental sulphur. Therefore, to develop a technology to recover thereby removed metals and leachable sulphate salts which are the primary cause of continuing residual contamination of complex sulphide ore tailings sites. Moreover, reprocessing of tailings is an alternative to be redeposited in a condition and in a manner that will ensure a long-term remediation process, but also looking for alternatives for its reuse, for example thickened tailings can be mixed with cement and used in construction or as backfill in underground mines.

\section{Results}

Project proposal for submission to Horizon 2020, topic: Raw material innovation action, identifier: SC5-14-2016-2017, second stage b) Processing of lower grade and/or complex primary and/or secondary raw materials in the most sustainable ways (2017).

\subsection{9 "Waste to Mine: From Pollution Source to Georesource"}

- Coordinator: Luleå University of Technology (LTU).

- Partners: Luleå University of Technology (LTU), Geological Survey of Finland (GTK), Kjeøy Research Center.

- NordMin funding: max. DKK 200,000. 
The global demand for metals and minerals is growing rapidly. Europe has a huge trade deficit for metallic minerals, and therefore needs to extract more of its own resources to reduce dependence. Given the non-renewable nature of mined resources, the sustainability of this industry and the efficient use of its resources for development remain crucial. Mining can become more sustainable by developing and integrating practices that reduce the environmental impact of mining operations and optimise mineral and metal extraction in mining operations.

Mine waste around the world is a source of pollution and social conflict (e.g. in Peru, there are around 8000 waste deposits registered and in Chile about 700 mine tailings, and about $30 \%$ of the social conflicts in Peru are related to mining and the associated water pollution). In many cases, the waste still has important amounts of valuable elements and minerals, sometimes elements with a higher grade than today's exploited mines. For example, in Chile, old waste deposits have around $0.3-0.6 \%$ wt. $\mathrm{Cu}$, and in Finland up to $0.3 \% \mathrm{Cu}$, while many mines such as Aitik in northern Sweden operate with $<0.4 \%$ wt. Cu. However, the value of mine wastes is not well known, as no or little information on mineralogical and geochemical characterisation of most waste materials is available. In addition, waste deposits can be potential sources of critical elements that have not been explored or exploited in the past. Mining can become more sustainable by developing and integrating practices that reduce the environmental impact of mining operations and optimise mineral and metal extraction in mining operations.

We propose to form a European consortium to address the Horizon 2020 call of "Societal Challenges 5 Work Programme 2016-2017 "Greening the economy" aiming to change mine waste into a new georesource by exploring them by mineralogical and geochemical characterisation and by developing new extraction techniques (e.g. biomining, geobiotechnology) in order to extract as many useful minerals and metals as possible. Once the economic value is extracted from the waste and harmful metal(oid)s and minerals separated, a final and safe deposition can be designed for the residual material, which could not be transformed into new products. This is in the line with the philosophy of the Strategic Innovation Programme for the Swedish Mining and Metal Producing Industry (STRIM) to promote the mining industry to produce zero waste beyond 2030.

Information will be collected in databases and linked to pre-existing databases like Minerals4EU, which includes volume, mineralogical and geochemical data, ore grade, detailed information of extraction and recovery method, and remediation strategies. Storage of data of mining wastes in the EU has been started in EU projects such as ProMine coordinated by GTK. This project will not only include mining wastes from Europe, but also from, for instance, South America, to produce an international database and make the information available to the mining industry, investors and researchers in order to promote the characterisation of old mine waste around the world and promote its exploitation as a new sustainable georesource.

The proposed consortium would include leading Research Institutions in raw material research around Europe promoting the EU-Latin America dialogue in raw 
materials to enhance the co-operation. The integration of Australian - Asian and South American partners is foreseen in order to ensure a global impact.

The consortium would include, in addition to the Scandinavian Countries (LTU, Sweden, Geological Survey of Finland, Kjeøy, Norway), European institutions such as CSIC, Barcelona, Spain, University of Huelva, Spain, RWTH Aachen Germany, BGR Germany, University of Wales, UK, Rumanian Academy, among others; and international partner institutions in Chile, Colombia, Peru, Brazil, Argentina, Mexico, Australia, among others.

\section{Results}

Project proposal for submission to Horizon 2020, early March 2017.

\subsubsection{0 "Extraction of resources from waste streams in the Nordic region"}

- Coordinator: UiT The Arctic University of Norway.

- Partners: UiT The Arctic University of Norway, Kjeøy Research and Education Center, University of Oulu, Linnæus University.

- NordMin funding: max. DKK 150,000.

Since 2003 , the prices of metals and minerals on international markets have risen significantly due to the increase in demand from the large emerging economies such as China and India. Europe has a huge trade deficit for metallic minerals, and therefore needs to extract more of its own resources to reduce this dependence. The expanding mining industry is an important economic engine for the northern regions and has to be developed in harmony with the environment. The mining industry is the most significant producer of solid, liquid and gaseous wastes. It is estimated that about $90 \%$ of the extracted materials become waste. Therefore, the extraction of metals needs to be performed in a more sustainable and environmental friendly way. This results in a push for extracting more resources from materials being exploited and reprocessing waste that has been generated. The proposed research aims to investigate the potential to reprocess and extract resources from waste streams of the mineral industries in the Nordic region. The research is divided into two work packages.

- Work Package 1: Reprocessing old iron and sulphidic mine wastes to obtain key elements:

- The potential for reprocessing old iron and sulphidic mine wastes to obtain key elements, such as scandium, iridium, vanadium, copper, zinc, and nickel, will be investigated by combining physical and geochemical methods. The physical methods include milling and ultrasound. The geochemical methods include acid and alkaline leach. In addition, the microbiological effects under different leaching settings will be studied to evaluate if there is need for leaching optimisation by improving the microbiological conditions. The proposed research will be conducted at the following test sites: Selvåg iron- 
vanadium deposit; Mustavaara mining site; Råna tailings, Ballangen; Sulitjelma Cu-Zn mining districts; Bjørkåsen tailings, Ballangen; and Bleikvassli waste rocks. Concentration of other rare elements will be assessed as part of a characterisation of the waste and ore material.

- Expected results: A small mobile leaching processing system will be developed since old most mine waste dumps are relatively small.

- Work package 2: Recovery of Vanadium from liquid waste streams:

- Vanadium and its compounds have multiple applications in industry, such as in alloys and as a catalyst. The EU is highly dependent on vanadium imports and the demand for vanadium will increase in the coming years. Vanadium is present in high concentrations in some industrial liquid streams, such as wastewater from synthesis gas scrubbers. The potential exists to recover vanadium from different liquid waste streams' separation processes, including dilute streams.

- This work package has three main objectives:

- Characterise existing liquid waste streams of vanadium.

- Investigate and optimise the vanadium affinity on selected sorbents and recovery from exhausted sorbent.

- Demonstrate the performance of best sorbent on pilot scale.

- Expected results:

- Optimised continuous recovery process for vanadium from liquid waste streams.

- Better understanding of the interaction between vanadium and different sorbents.

Results

Project proposal submitted to the Nordic Green Growth Research and Innovation Programme funded by NordForsk. Another project proposal will be submitted to the Interreg Nord (deadline February 2017).

\subsubsection{1 (NEXT) "Next generation of EXtraction \& Separation Technologies"}

- Coordinator: Luleå University of Technology (LTU).

- Partners: Luleå University of Technology (LTU), Norwegian University of Science and Technology (NTNU), The University of Oulu (UO), Boliden AB.

- NordMin funding: max. DKK 200,000.

Due to the steady depletion of high grade relatively easy to process ores, the mineral industry is confronted with a challenging task of finding more efficient and selective reagents to exploit mining wastes, i.e., low grade, complex and disseminated type of ore deposits and old tailing dumps. This project targets sustainable use of natural resources by developing novel methods to extract valuable minerals and metals from 
mine tailings with a particular focus on the extraction and separation of Rare Earth Elements (REE) from tailings. The project will utilise the combined knowledge of novel collector synthesis, minerals chemistry and advanced spectroscopy (Prof. Antzutkin's group, LTU); DFT calculations of interactions between collectors and mineral surfaces and flotation (Prof. Rao's group, NTNU); and advanced NMR imaging and modelling of complex pulp and solution mixtures in the extraction and separation processes and $a b$ initio quantum mechanical calculations on REE collector complexes (Assoc. Prof. Telkki's and Prof. Vaara's groups, UO).

Part A - Extraction of valuable minerals from mining waste: Development of next generation "mineral specific collectors" for separating valuable minerals from ores is becoming inevitable. A series of novel collectors with a fixed alkyl chain length, but with two (or more) functional groups with varying distances between them were synthesised at LTU. Preliminary flotation and selectivity tests using these collectors, at LTU and at NTNU, were promising. Flotation behaviour of different LKAB-based calcium minerals and Boliden $A B$ based sulfide minerals will be tested using bench scale flotation to elucidate mineral specific adsorption, i.e. a relationship between "varying distances between the reagent head groups" and "distances between the active adsorption sites on mineral surfaces". These experimental studies will be supported by DFT calculations of interactions between such designed collectors and different mineral surfaces of interest. After optimisation of the flotation conditions with pure minerals, the novel collectors will be practically employed to extract valuable minerals from the accumulated flotation tailings at various minefields.

Part B - Extraction of REE from mining waste: LTU and $U O$ are combining quantum mechanical calculations with spectroscopic methods (NMR and single crystal XRD) to elucidate structures and properties of complexes of REE with different collectors. This study indicates a possibility of separating REE by finding the correct ligand forming different types of complexes depending on specific tiny variations in chemistry of $f$ group metals such as REE. With such acquired knowledge of interactions between various collectors and REE minerals and REE ions in solutions, more efficient and more environmentally friendly (next generation) methods for concentration and separation of REE from the present flotation tailing (waste) will be developed.

Results

Project proposal for submission to $\mathrm{H}_{2020} \mathrm{SC}_{5-14-2016-2017}$ call (deadline March 7, 2017).

\subsection{Postgraduate education courses}

In order to foster collaboration in research and education between Nordic countries, NordMin developed pertinent postgraduate education courses offered to MSc students, PhD students and other stakeholders in the Nordic countries interested in the raw materials sector. Scholarships were offered to the MSc and PhD students from Nordic countries in order to cover their travel and accommodation costs. Lecturers were well-known experts from the Nordic countries representing academia, industry, 
research organisations and public authorities. Three PhD courses and one MSc course were organised by NordMin during the project period.

\subsubsection{PhD-course on minerals industry sustainability within a Nordic context}

- NordMin funding: DKK 400,000.

The first PhD course was held in Luleå, Sweden, December 8-12, 2014 and the topic was the mineral industry sustainability within a Nordic context". The course was hosted by Luleå Technical University, and run by the NordMin management. It was advertised to potential participants via email and the NordMin webpage.

A total of 22 participants (20 PhD students, 1 MSc student and 1 representative from industry) representing all Nordic countries participated to the course and 14 students received scholarships up to a max. 10,000 DKK/student in order to cover their travel and accommodation costs.

To be eligible for five ECTS, the students needed to attend all the lectures ( 32 hours) and participate in an exercise (8 hours).

The speakers were well-known professionals representing academia, industry, research institutes and public authorities in the Nordic region.

\subsubsection{Gold from Bedrock to Bullion: Sustainable Mining}

- NordMin funding: DKK 234,360.

The second NordMin educational course was held in Oulu, Finland, January 18-22, 2016 and it was hosted by the University of Oulu, Oulu Mining School.

The programme included four days of lectures and one day was reserved for the field trip to Agnico Eagle, Kittilä gold mine.

On the first day there were two speakers, research professor Ferenc Molnar from the Geological Survey of Finland, lecturing on "Occurrence of gold in bedrock and gold mineralogy" and exploration manager Erkki Vanhanen from Mawson Resources Ltd., whose topic was: "Gold exploration: Rompas case". On the evening, the project manager for OMS Research Centre, Ilkka Hynynen, introduced the flotation-based mini-pilot scale concentrator plant to the students. On the second day, there were three speakers: Timo Lindborg, adjunct professor of the University of Oulu and CEO of Sotkamo Silver company, gave a lively and practical example of economic planning of a mine entitled: "Planning and execution of a mine project: economic perspective". Following this, professor Paavo Perämäki and PhD Jaakko Rämö gave a detailed talk about chemistry and analytics with the title: "Chemistry and analytics of gold and associated compounds". The third day was reserved in its entirety for an important part of gold production; the actual processing. The lectures were given by Jaakko Leppinen, technology director from Outotec, with the title: "Gold extraction techniques". On the fourth day, there was a field trip to Agnico Eagle's Kittilä Mine. The day started with two lectures, the first dealing with the geology and mineralogy of the gold deposit was 
given by the chief geologist Jukka Välimaa while the second was given by the sustainable development manager Anita Alajoutsijärvi, and was entitled: "Environmental challenges of gold mining". Following the lectures, there was a round trip to the mine area. On the fifth and final day of the course, the final speaker, PhD Marja Liisa Räisänen from the Geological Survey of Finland, focused on environmental impact assessment and closure of a mine.

The total number of participants on the course was $45 ; 30$ of them being PhD students and 15 MSc students, representing all Nordic countries.

The PhD students were accepted to the course based on their applications. The MSc students from relevant subjects were also given the right to take part in this course; however, a maximum number for them was set.

The PhD students coming from outside the University of Oulu were given a scholarship based on their actual travel costs. The scholarship was given to 23 students and it varied from EUR $\sim 500$ to EUR 1,050 with an average of EUR $\sim 750$.

To be eligible for five ECTS, the students needed to attend all the lectures, take part on a field trip and write an essay on the subject.

\subsubsection{Deep-sea mineral resources and prospects of underwater mining: geological, environmental and technological challenges ahead}

- NordMin funding: DKK 334,450.

The third NordMin educational course was a PhD course and it was held in Bergen, Norway, October 3-11, 2016, and was hosted by the University of Bergen, Centre for Geobiology.

The course was jointly organised by Norway and Iceland and included lectures and practical sessions covering the three main aspects of deep-sea mining: (1) the current knowledge on seafloor hydrothermal systems, their diversity, characteristics, and resource quantification, (2) techniques for seafloor exploration and technology available for exploitation, (3) environmental impacts and national regulations.

The lecturers were experts in the field, representing universities, research institutes and industry.

A total of 22 participants attended the course and 15 students received scholarships up to a max. 8,000 DKK/scholarship in order to cover their travel and accommodation costs.

\subsubsection{The Business of Exploration, from the ground to the stock market}

- NordMin funding: DKK 400,000.

The fourth and final NordMin educational course was an MSc course and it was held in Reykjavik, Iceland, October 31-November 4, 2016. The course was arranged by National Energy Authority of Iceland (Orkustofnun) in cooperation with the Faculty of Earth Sciences, University of Iceland and ÍSOR - Iceland GeoSurvey, and it was a registered at the Faculty of Earth Sciences, University of Iceland and worth three ECTS. 
The course covered a wide range of topics related to the business of exploration, or from the ground to the stock market. The course was primarily offered as lectures, but it also included student group exercises. There was a half-day excursion to the Thormodsdalur gold prospect, followed by a visit to the Hellisheiði geothermal power plant. Lecturers were well known experts in their fields, coming from the Geological Survey of Finland (GTK), Finnish Association of Extractive Industries, Faculty and Institute of Earth Sciences at the University of Iceland and ÍSOR - Iceland GeoSurvey. The course had 35 participants ( $16 \mathrm{MSc}$ students, 7 PhD students and 12 participants representing industry, public authorities and NGOs), and it was a unique opportunity for Nordic students to meet, network and discuss business in relation to exploration, and it therefore attracted students with different backgrounds and disciplines from all the Nordic countries. A total of 11 scholarships up to a max. DKK 9,000, were offered to Nordic students who were studying the mining industry in their thesis work, in order to cover their travel and accommodation costs.

\subsection{Outreach}

The NordMin management has been actively promoting the project at different international conferences and workshops. Some activities have been of strategic importance and the attendance and support of NordMin for the Nordic Day at Prospectors and Developers Association Convent (PDAC) held annually in Toronto, Canada, has been one such activity. Outreach actions can be divided into three main activities:

- Printed promotional material.

- Conference presentations.

- Financial and logistic support promotion a sustainable Nordic mining industry.

The main outreach actions under each activity are listed below.

\subsubsection{Printed promotional material}

- A NordMin brochure was produced in 2014 and used as promotional material at various occasions: Nordic Council of Ministers, 2014. A Nordic Network of Expertise for a Sustainable Mining and Mineral Industry. ISBN 978-92-893-2698-8. DOI http://dxdoi.org/10.6027/ANP2014-714. ANP 2014:714. 16pp.

- Roll-ups were produced and displayed at conferences and workshops (see below). 


\subsubsection{Conference presentations}

NordMin was presented at the following Conferences:

- Prospectors and Developers Association Convent (PDAC), Toronto, Canada, March 2014.

- Prospectors and Developers Association Convent (PDAC), Toronto, Canada, March 2015.

- Prospectors and Developers Association Convent (PDAC), Toronto, Canada, March 2016.

- Prospectors and Developers Association Convent (PDAC), Toronto, Canada, March 2017.

- Fennoscandian Exploration and Mining meeting 2013, Levi Finland, oral presentation by Riikka Aaltonen (NordMin board).

- Fennoscandian Exploration and Mining meeting 2015, Levi Finland, booth (jointly with LTU, oral presentation by Pär Weihed (in presentation of STRIM).

- The High North Conference - Sustainable Development of the Top Mining Region of the World, 2013, Voksenasen, Norway, oral presentation by Pär Weihed.

- Nordic Aggregates and Stones - Information and Collaboration, 2014, Trondheim, Norway, oral presentation by Betty Christakopoulou.

- International Symposium on Northern Development 2015, Quebec, Canada, oral presentation by Betty Christakopoulou.

- Mining and Society in the Arctic, 2015, Sisimiut, Greenland, oral presentation by Betty Christakopoulou.

- GeoNor 2016, Mo i Rana Norway, oral presentation by Betty Christakopoulou.

- EraMin Conference 2014 Budapest Hungary, oral presentation by Pär Weihed.

- Framtidens Gruv och Mineral 2013, Stockholm Sweden, oral presentation by Pär Weihed. 


\section{External evaluation}

In compliance with the NordMin Strategic research and Innovation Agenda, the NordMin board decided to conduct an external evaluation of NordMin and a tender was won by the company Faugert \& Company, part of Technopolis group. The evaluation resulted in a report $^{20}$ to the board in December 2016. The main outcomes of this report are:

"NordMin is an unusual programme and there is no doubt about NordMin's importance and potential for Nordic networking within the mineral field. There is general agreement that NordMin is on the right track and that there is a potential for NordMin to become a successful Nordic network of expertise and research focusing on sustainable non-energy raw materials.

Given the importance, uniqueness and successful start-up of the programme, there are good reasons for the NCM to pursue the programme.

NordMin is, in many respects, an untested model, and it may be particularly important to consolidate that which works well before the next step is taken. There are a number of merits worth highlighting:

- A large amount of activities have started in a short time with participants from all the Nordic countries

- NordMin has quickly found a good management structure and good administrative practices

- NordMin covers all possible strands of research in this area; environmental protection and social cohesion within one of the six core themes

- There is a clear enthusiasm and conviction at all levels that the current strategy is the right one

The time aspect is important: NordMin must be judged by where it is on a "development curve", and immediate results and effects should not be expected. NordMin should be allowed another programme period in which to focus on increasing the interaction with industry, and to gradually improve the functioning of a Nordic platform for networking and a catalyst for mutually beneficial collaboration. Being a newly established programme, there are, naturally, some specific areas for improvement:

Research projects

- Keep the funding for two or four more years to better comply with the education systems and to simplify engagement of PhDs

- When the results of the projects start to become apparent, it is important to make sure to disseminate them at an early stage. The project decisions should specify how the project results would be disseminated, both within scientific circles and to the industry. Today, the knowledge of the project results is weak even within the NordMin community

Workshops

- Let the workshops grow bigger. This form of network activity is much appreciated and should be prioritised before the other core activities

- Ensure an agenda that suits both R\&D performers and industry

${ }^{20}$ Annika Olsson, Miriam Terrell, Markus Lindström and Erik Yläneva: Evaluation of NordMin, technopolis |groupl, December 2016, 60 pp. 
- Expand the facilitation to include matchmaking between industry and academia, aside from the facilitation of networking. One example of such facilitation is the university tool AIMday (Academia Industry Meeting Day). This is used by many universities as a way of increasing knowledge exchange, making contacts and initiating collaboration between academia and industry. Specific questions brought forward by companies are matched with the academic expertise. The outcome is a day of so-called 'one question, one hour' workshops where teams of approximately five to twelve individuals (from academia and industry) candidly discuss each topic in the format of a round-table discussion.

Increase industry participation

- Find ways to promote proactive engagement, for instance through distributing outreach information or visits to potential companies, etc.

- Let the industry set the agenda for meetings and projects and try to bring scientific competences together that correspond to the needs of the industry

- Make sure to have company representatives in the management group (not only representation by industry associations)

- Consider additional "offers" and develop forms for networking and interaction between companies and PhD and Master students, for example facilitate industrial PhDs, Master's theses, project- and trainee work

- Practise patience and change to longer programme periods; it takes time to build up an effective and trustful cooperation between companies and university researchers

Increase the efforts in terms of internal and external communication and information dissemination.

For example, develop a communication plan for the programme

Management

- The advisory board does not function optimally. Focus the resources on the steering committee and the project management in order to increase the efficiency of the administration

- Express the role of the management function more clearly, particularly the roles of the advisory board and the national coordinators

Objectives

- Facilitate opportunities to evaluate objective fulfilment and reformulate the objectives based on the SMART criteria; Specific (target a specific area for improvement), Measurable (quantify or at least suggest an indicator of progress), Attainable (specify who will do it), Realistic (state what results can realistically be achieved, given available resources), Time-related (specify when the result/s can be achieved)

- Many of the goals are very ambitious. Consider which goals are the most important to keep and which ones are not. Such a task helps in adapting the ambitions to prevailing conditions" 


\section{Recommendations}

Based on the experience from the management of NordMin, the work with the Steering committee, advisory board, national coordinators and backed up by the external evaluation, some conclusions and recommendations can be made regarding the NordMin project, its executions and potential for further Nordic collaboration. As stated in the external evaluation report, the concept of NordMin is new and "in many respects, an untested model". This project was unique in its setup and funding model through the priority budget by the Swedish Presidency when entering into office in 2013. In the early work with finding the organisational structure, one idea was to establish a Nordic institute for raw materials. For various reasons this did not materialise, but given the importance of raw materials for the future society, not least with respect to many green technologies for emerging sustainable energy, transport and urbanised society solutions, a joint Nordic initiative over time has its merits. All Nordic countries are ranked highly in their ambitions for finding sustainable solutions for the future, there is a strong emphasis on innovation and entrepreneurships and when the Arctic is high on the political agenda a joint Nordic action is called for.

It was clear from the setup of NordMin that funding through the Nordic Council of Ministers was limited to three years, unless other initiatives materialised. Within NordMin there was an ambition to secure further funding to maintain the established networks. An application was also submitted to Nordforsk for a Centre of Excellence (see above); however, this was not funded. A reflection from the management is that, within the framework of the Arctic and Nordic collaboration, less focus is put on sustainable development of the Arctic in terms of creating a competitive and sustainable environment for new enterprises and industrial development. A continued Nordic support for sustainable development of the extractive industry sector could, if developed in the right way, be a catalyst for a society growing in harmony with sustainability values, not jeopardising but rather strengthening environmental, societal and economic capabilities in the North.

It is indicated in the external evaluation support that perhaps the organisation was too complex and involved too many bodies and that possibly the objectives and goals, given a limited three-year project, were too ambitious. This may also be reflected in the difficulties of engaging industry in NordMin on a more operational level. However, again based on the external review the added value and long-lasing benefits of NordMin can be identified, such as:

- A large number of activities have started in a short time with participants from all the Nordic countries.

- NordMin has quickly found a good management structure and good administrative practices. 
- NordMin covers all possible strands of research in this area; environmental protection and social cohesion within one of the six core themes.

- There is a clear enthusiasm and conviction at all levels that the current strategy is the right one.

Alongside the recommendations from the external evaluation, it is here concluded that the NordMin project brought together people from academia, industry, research institutes and the public sector from all Nordic countries in a way that has not happened before in the area of raw materials in its broadest sense, not only including technology and science but also addressing raw materials from a societal aspect, not least trying to define sustainability criteria for the sector. Although each jurisdiction is different in detail, the Nordic countries largely have a common view on how raw materials can play an important role in building the future sustainable society, This is based on a common Nordic ground defined by our common history and culture which, in turn, has led to societies which are in many respects unique, but which to a large extent share common values on which collaboration can be developed in the extractive raw materials sector. The following recommendation can be made based on this:

- Evaluate the possibility of establish a Nordic research institute on raw materials.

- Define a common Nordic programme supporting research on raw materials, i.e. through Nordforsk.

- Define a common Nordic platform for triple helix-type research and innovation (the external evaluation mention a so-called AIM-day).

- Evaluate how Nordic Innovation can play a role (a last minute decision from Nordic Innovation made them withdraw a support for joint actions with NordMin).

- The NCM should be a catalyst for joint Nordic actions on raw materials, also by joint actions within European framework programmes (here it can be said that a joint strategy both for the EIT RawMaterials KIC and the ERA-MIN programme could have been beneficial). 


\section{NordMin Publications}

\subsection{Publications}

Wahlström et al. (2017). Water Conscious Mining (WASCIOUS). TemaNord report TN2017:525. Nordic Council of Ministers. https://doi.org/10.6027/TN2017-525

Sinche-Gonzalez, M., Lamberg, P., Suup, M. (2016). Geochemical model and simulation of water balance for mining operations: Journal of Modern Environmental Science and Engineering, paper No MESE20160905-1, vol. 11.

Mamelkina, M.A., Särkkä, H., Tuunila, R., Sillänpää, M., Häkkinen, A. (2016) Sulphate removal by electrocoagulation using iron electrodes: laboratory studies. Submitted to Journal of Water Process Engineering (Maria Mamelkina, LUT), November 2016.

Mamelkina, M., Tuunila, R., Cotillas, S., Lacasa, E., Saez, C., Sillanpää, M., Häkkinen, A., Rodrigo, M.A. (2017). Removal of sulphate from mining waters electrocoagulation. Submitted to Separation and Purification Technology, January 2017.

Mamelkina, M.A., Vasilyev, F., Tuunila, R., Sillanpää, M., Häkkinen, A. (2017). Investigation of parameters influencing the sulfate removal by electrocoagulation. For submission to Electrochemica Acta, autumn 2017.

Mamelkina, M., Vainio, H., Tuunila, R., Sillanpää, M., Häkkinen, A. (2017). Combined electrocoagulation and post-treatment operation for water reuse and removal of harmful contaminants. For submission to Separation and Purification Technology, autumn 2017.

Guarnieri, P., Brethes, A., Rasmussen, T. M., Blischke, A., Erlendsson, Ö., Bauer, T (2017). CRUSMID-3D Crustal Structure and Mineral Deposit Systems: $3 D$ modelling of base metal mineralisation in Jameson Land and nickel mineralisation in Disko-Nuussuaq. TemaNord report TN2016:562. Nordic Council of Ministers. https://doi.org/10.6027/TN2016-562

Guarnieri, P., Brethes. A., Rasmussen, T.M., Geometry and kinematics of the Triassic Rift in Jameson Land (East Greenland), submitted November 2016 to Tectonics.

Brethes. A., Guarnieri, P., Rasmussen, T.M., Bauer, T. Analysis of aeromagnetic data in Jameson Land, central East Greenland: crustal structures and mineralization systems. For submission to Geophysical prospecting or Geophysics.

Brethes. A., Rasmussen, T.M., Guarnieri, P., Bauer, T. Architecture and thickness estimation of the Klitdal Basin using $3 \mathrm{D}$ geologically- constrained inversion of aeromagnetic data in Jameson Land, central East Greenland - to submit in Tectonophysics.

Brethes. A., Rasmussen, T.M., Guarnieri, P., Baver, T. Mapping Induced Polarization effects in TEM data using Self-Organizing Maps and inversion for their Cole-Cole parameters, Central East Greenland - to submit in Geophysical prospecting or Geophysical interpretation.

Brethes. A., Rasmussen, T.M., Guarnieri, P., Bauer, T. Synthetizing magnetic signal decomposition images using Self-Organizing Maps for geological interpretation - Case study over the Pb-Zn Blyklippen mine, Mesters Vig, central East Greenland - for submission in Interpretation.

Johannesson, B., Sigfusson, T. I., Franzson, H., Erlendsson, Ö., Harðarson, B. S., Thorhallsson, E. R., Arnason, A. B., Azrague, K., Wiik, M. R. K., Vares, S., Kronlöf, A., Koskinen, P., Vehmas, T. (2017). GREENBAS Sustainable Fibres from Basalt Mining. TemaNord report TN2016:564. Nordic Council of Ministers. https://doi.org/10.6027/TN2016-564

B. Johannesson og T.I. Sigfusson. Blátrefjar (in Icelandic). Fréttabréf Steinsteypufélags Íslands, 28. árgangur, 1 tbl, bls. 12-13, Febrúar 2015. 
Andri Gunnarsson, Eythor Rafn Thorhallsson, Jonas Thor Snaebjornsson. Simulation of experimental research of concrete beams pre-stressed with bfrp tendons, Nordic concrete research symposium 2014, Reykjavik. Vodskov: 2014, pp. 153-156.

Eythor Thorhallsson, Todor Zhelyazov, Andri Gunnarsson and Jonas Thor Snaebjornsson. Concrete beams reinforced with prestressed basalt bars. fib Symposium. Concrete - Innovation and Design, Copenhagen, Denmark 18-20 May, 2015.

Todor Zhelyazov, Eythor Thorhallsson and Jonas Thor Snaebjornsson. Simulation of experimental research on strengthening concrete columns by basalt fibre sheets fib Symposium. Concrete - Innovation and Design, Copenhagen, Denmark 18-20 May, 2015.

Kamal Azrague, Marianne Rose Inman, Lisbeth-Ingrid Alnæs, Reidun Dahl Schlanbusch, Birgir Jóhannesson, Thorsteinn Ingi Sigfusson, Eythor Rafn Thorhallsson, Hjalti Franzson, Arni B Arnason, Sirje Vares: "Life Cycle Assessment as a tool for resource optimisation of continuous basalt fibre production in Iceland" in Life Cycle Assessment and Other Assessment Tools for Waste Management and Resource Optimization, Professor Umberto Arena, Second University of Naples, Italy Professor Thomas Astrup, Denmark Technical University, Denmark Professor Paola Lettieri, University College London, United Kingdom Eds, ECI Symposium Series, (2016). http://dc.engconfintl.org/lca_waste/10

Eythor Rafn Thorhallsson, Jónas Thór Snaebjornsson: Basalt Fibres as New Material for Reinforcement and Confinement of Concrete. Solid State Phenomena 04/2016; 249. DOI:10.4028/www.scientific.net/SSP.249.79.

Eythor R Thorhallsson and Jón Ó Erlendsson. Continuous Basalt Fibre as Reinforcement Material in Polyester Resin. In proceedings of 2nd International conference on Mechanics of Composites, Porto 2016.

Eythor Rafn ThPorhallsson, Gudmundur Ingi Hinriksson and Jonas Thor Snæbjornsson: Strength and stiffness of glulam beams reinforced with glass and basalt fibres. Accepted for publication in Journal of Composites Part B.

Marianne Inman, Eythor Rafn Thorhallsson, Kamal Azrague. A mechanical and environmental assessment of basalt fibre reinforced polymer (BFRP) rebar and steel rebar in concrete beams. Accepted for publication in Energy Procedia.

Iveta Novákováa, Eythor Thorhallsson, Ólafur Wallevik, Lenka Bodnárováa: influence of porosity of basalt aggregates on fire resistance and freeze-thaw durability of fibre reinforced concrete. Will be in proceedings of 11th HPC and the 2nd CIC in Tromsø in March 2017.

Grant, T.B., Larsen, R.B., Anker-Rasch, L., Grannes, K.R., Iljina, M., McEnroe, S., Nikolaisen, E., Schanche, M., Øen. E. (2016). Anatomy of a deep crustal volcanic con-duit system; the Reinfjord Ultramafic Complex, Seiland Igneous Province, northern Norway. Lithos, 252, pp. 200-215.

Grannes, K.R. (2016) Cryptic Variations of Olivene and Clinopyroxene in the RF-4 Drill-Core: - A geochemical study of the Reinfjord Ultramafic Complex, Norway. MSc thesis, NTNU, Trondheim, pp. 223.

Nikolaisen, E. (2016) Platinum Group Elements in the Reinfjord Ultramafic Complex.

MSc thesis, NTNU, Trondheim, pp. 238.

Pastore, Z., Fichler, C., McEnroe, S. (2016) The deep crustal structure of the mafic-ultramafic Seiland Igneous Province of Norway from $3 \mathrm{D}$ gravity modelling and geological implications. Geophysical Journal International 2016. DOI:10.1093/gji/ggw362.

Johansson, Maria \& Ringblom, Lisa (forthcoming, submitted 2014). The business case of gender equality in Swedish forestry and mining - exploring the terms for organizational change.

Ringblom, Lisa \& Abrahamsson, Lena (forthcoming, submitted 2016). Renegotiation of the mine? Gender, work and transformation in the male dominated mining industry. 


\subsection{Abstracts, Conferences, Seminars}

Brethes, A., Rasmussen, T.M., Guarnieri, P., Bauer, T. (2015, August). 3D modelling of the basemetal mineralized Jameson Land Basin (central East Greenland) using geologically constrained inversion of magnetic data. Paper presented at the international conference Saying goodbye to a 2D Earth, Margaret River, Western Australia.

Brethes, A., Rasmussen, T.M., Guarnieri, P., Bauer, T., (2016, June). Mapping and characterization of Induced Polarization in airborne TEM data from central East Greenland application of a Self-Organizing Map procedure. IP2016 - 4th International Conference on Induced Polarization, Aarhus, Denmark.

Brethes, A., Guarnieri, P., Rasmussen, T.M., Bauer, T. (2016, September). Geological Analysis of Aeromagnetic Data over the Blyklippen lead-zinc mine at Mesters Vig, central East Greenland. EAGE Near surface Geoscience 2016, First conference on Geophysics for Mineral Exploration and Mining, Barcelona, Spain.

Mamelkina, M., Vainio, H., Tuunila, R., Sillanpää, M., Häkkinen, A. (2017). Electrocoagulation and solid-liquid separation treatment of real mining waters, solids characterization. Abstract submitted: IMWA 2017 Congress, Lappeenranta, Finland, 25-30 June, 2017.

Presentation about WASCIOUS in the NordMin Helsinki workshop on October 20, 2016 (Margareta Wahlström, VTT).

Mamelkina, M.A., Vasilyev, F., Tuunila, R., Särkkä, H., Lund, C., Lamberg, P., Sillanpää, M., Häkkinen, A. (2016). Sulphate removal by electrocoagulation: operational conditions and solid characterization, 5th International Congress on Water Management in Mining 2016, May 1822, Santiago, Chile, oral presentation, conference paper.

Mamelkina, M.A., Tuunila, R., Cotillas, S., Lacasa, E., Rodrigo, M.A., Sillanpää, M., Häkkinen, A. (2016). Electrochemical sulphate removal from mining waters using iron and aluminium electrodes. 1st International Conference on Sustainable Water Processing, 11-16 September 2016, Melia Sitges, Spain, poster presentation.

Mamelkina, M.A., Tuunila, R., Sillänpää, M., Häkkinen, A. (2016). Removal of sulphate from mining waters by electrocoagulation. 16th Nordic Filtration Symposium, 24-26 August 2016, Lappeenranta, Finland, oral presentation.

Mamelkina, M.A., Särkkä, H., Tuunila, R., Sillänpää, M., Häkkinen, A. (2015). Sulfate removal from mining waters by electrocoagulation: from laboratory to a mine. 7th European Summer School in Electrochemical Engineering, 22-26 June 2015, Leeuwarden, The Netherlands, poster presentation.

Project presentation for TEKES/Green Mining seminar on May 21, 2015 in Euromining, Tampere, Finland (Margareta Wahlström, VTT).

Project and especially results from WP2 presented in SVEMINs miljökonferens on 7 th of October 2015 (Tommi Kaartinen, VTT).

Sinche-Gonzalez, M., Lamberg, P., Suup M. (2016). Model and simulation of water balance for mining operations: case study Svappavaara iron mine. 5 th International Congress on Water Management in Mining 2016, May 18-22, Santiago, Chile, oral presentation, conference paper.

Sinche-Gonzalez, M., Lamberg, P. (2016). Geochemical water balance by modeling and simulation in mining - Water Conscious Mining (WASCIOUS) Project (Luleå conference February, 2016).

Sandru, M., Mamelkina, M.A., Johnsen, H., Häkkinen, A. (2016). Exploring the possibilities of a hybrid membrane-electrocoagulation system for sulphate removal from mine waters. 16th Nordic Filtration Symposium, 24-26 August, 2016, Lappeenranta, Finland, oral presentation.

Renser gruvevann uten kjemikalier. 2015. Gemini: http://gemini.no/2015/og/renser-gruvevannuten-kjemikalier/http://gemini.no/2015/og/renser-gruvevann-uten-kjemikalier/ (Marius Sandru, Sintef).

NordMin steering group meeting, Stockholm, November 11, 2014, Project presentation (Margareta Wahlström, VTT). 
Fichler, C., McEnroe, S., Pastore, Z., Michels, A. (2016). Subsurface models of ser-pentinite/ peridotite bodies, onshore and offshore Norway. Abstract, 4 th Serpentine Days, September 25-29, Sete, France.

Fichler, C., McEnroe, S., Michels, A., Pastore, Z., Strømøy, E. (2016). Integrated geophysical interpretation of ultramafic rocks in the crust of onshore and offshore Norway. Abstract, Onshore-Offshore relationsships on the north atlantic margins, October 18-19, Trondheim, Norway.

Fichler, C., Pastore, Z., McEnroe, S. (2017). Large ultramafic complexes and meta-morphic processes from the Seiland Igneous Province to the Veslemøy High, Barents Sea. NGF Winter Conference, January 9-11, Oslo, Norway.

Grannes, K.R., Larsen, R., Grant, T. The Reinfjord Ultramafic complex; petrology and geochemistry. Nordic Winter Meeting, Helsinki, Finland, 2016.

Grant, T.B., Larsen, R.B., Müller, A. (2016). Composition and evolution of plume melts in the lower crust; Seiland Igneous Province. Nordic Winter Meeting, Helsinki, Finland, 2016.

Grant, T.B., Larsen, R., Iljina, M., Schanche, M. (2015). The Reinfjord Ultramafic Complex, Seiland Igneous Province, Norway. 25rd annual VM Goldschmidt conference (Prague, Czech Republic 2015).

Grant, T.B., Larsen, R.B. (2015). The Reinfjord Ultramafic complex, Seiland Igneous Province, Northern Norway. International Conference on Arctic Margins, Trondheim, Norway.

Larsen R.B., Grant T., Sørensen B., McEnroe S. (2016) Mixing - Mingling and Modification of Magmas in a Giant Deep Crustal Magmatic Reservoir: The Seiland Igneous Province, Northern Norway. AGU autumn meeting, 2016.

Larsen, R.B., Grant, T., Sørensen, B., Nikolaisen, E., Grannes, K.R.B., Iljina, M, Schanke, M. PGE$\mathrm{Ni}$-Cu deposit formation in a deep-crustal ultramafic conduit system. The Seiland Igneous Province, North Norway. 35th International Geological Congress, Cape Town, South Africa.

Larsen, R.B. Grant, T.B. (2015). Portrait of giant magmatic conduit system at the roots of the crust: the Seiland Igneous Province, northern Norway. GSA, Baltimore, Maryland, USA, 2015.

Larsen, R.B., Iljina, M., Grant, T., Schanche, M. (2015). Ultra-mafic hosted Ni-Cu-Pt-Os-Au deposits in the Seiland Igneous Province (SIP), Norway. AGU-GAC-MAC-CGU joint assembly, Montreal.

Nikolaisen, E.S., Larsen, R.B.E., Grant, T., Sørensen, B.E. The hunt for platinum group minerals in the Reinfjord Intrusive complex. Nordic Winter Meeting, Helsinki, Finland, 2016.

Pastore, Z., Church, N.S., ter Maat, G. W., Michels, A., McEnroe, S. Fichler, C., Larsen, R.B. (2016) Large-scale magmatic event, magnetic anomalies and ore exploration in northern Norway. AGU autumn meeting, 2016.

Pastore, Z., Fichler, C., Church, N.S., McEnroe, S. (2015) Geophysical Interpretation of Mantle Magmatism in the Seiland Province: the Geometry of the Reinfjord Ultramafic Complex. AGU autumn meeting, 2015.

Pastore, Z., Fichler, C., McEnroe, S. (2015) Potential field modelling of the Seiland Igneous Province in the geodynamic framework of the northern Baltican margin. ICAM, 2015.

Pastore, Z., Fichler, C., McEnroe, S. (2016) The deep structure of the Seiland Igneous Province: A major feature at the southwestern border of the Barents Sea. Onshore-Offshore Relationships On The North Atlantic Margins, 2016.

Pastore, Zeudia; Fichler, Christine; McEnroe, Suzanne.

The deep structure of the Seiland Igneous Province (Norway): 3D gravity and magnetic modelling. IUGG 2015; 2015-06-22-2015-06-2 NTNU.

Pastore, Z; McEnroe, Suzanne; Fichler, Christine. (2015) Geophysical Interpretation of Mantle Magmatism in the Seiland Province and adjacent Barents Sea: Implications for tectonic emplacement of the Kalak Nappe Complex. AGU autumn meeting, 2015.

Sørensen B.E., Hjelen, J., Breivik, T., Yu, Y., Larsen, R., Grant, T. Advantages of Offline EBSD On Geological Samples. SCANDEM 2016, NTNU, Trondheim.

Sørensen B.E, Grant T., Larsen R.B., (2016) Record of a Lower Crustal Fossil Earth-quake Initiated by $\mathrm{CO}_{2}$ Flux and Reaction-driven Strain Softening. AGU autumn meeting, 2016. 
Sørensen, B.E., Grant, T.B. Larsen, R.B., Raanes, M. (2015). Coupled reaction driven deformation, strain softening and $\mathrm{CO}_{2}$ metasomatism in peridotites from the Rein-fjord Ultramafic Complex, northern Norway, GSA, Baltimore, Maryland, USA, 2015.

ter Maat, G.W., Michels, A.C., Pastore, Z., McEnroe, S.A. (2015). A rock- and paleo-magnetic study of the ultramafic rocks of the Reinfjord intrusion, Northern Norway. IUGG 2015, Prague, Czech Republic.

ter Maat, G., Church, N., Michels, A., Pastore, Z., Biedermann, A., McEnroe, S., Larsen, R. (2016): Rock magnetic properties of a deep crustal volcanic system: The Reinfjord Ultramafic Complex, Seiland Igneous Province, Northern Norway. 15th Castle Meeting 2016, New Trends on Paleo, Rock and Environmental Magnetism, Dinant, Belgium.

Andersson, Lisa, Johansson, Maria, Andersson, Eira \& Lindberg, Malin. Constructions of gender equality in male-dominated industries - voices from the Swedish mining and forestry sector. G14 - To challenge the power, 26-29 November, 2014, Umeå, Sweden.

Ringblom, Lisa \& Johansson, Maria. "Gender equality as a matter of course" Narratives from the mining and forestry sectors in Sweden. FALF - Annual national working life conference, 10-12 June 2015, Landskrona, Sweden.

Andersson Eira \& Ringblom Lisa. Men's agency and resistance in the gendered mining workers' collective. GWO2016, 29 June-1 July 2017, Keele, England.

Ringblom, Lisa. Gender equality - for a social sustainable development in Nordic mining. Research workshop "Responsible Mining \& Environmental and Social Sustainability", 29 October 2015, Oulu, Finland.

Ringblom, Lisa. Cracks in the workers collective? Windows for change towards equal gender patterns in mining workplaces. Poster session at Forte Talks, 8-9 March 2016, Stockholm, Sweden.

\subsection{NordMin workshops}

Guarnieri, P., Brethes, A., Rasmussen, T. M., Bauer, T., Blischke, A., Erlendsson, Ö. (2016). CRUSMID-3D. NordMin Workshop "How to go further in Nordic collaboration in the mining research and education" October 19, 2016 Helsinki, Finland.

Guarnieri, P. and Brethes, A. (2015) From 3D Photomapping to 3D modelling. Nordmin workshop, March 21-25, 2015 Reykjavik, Iceland.

Eythor. R. Thorhallsson, Haraldur Audunsson, Jonas Thor Snaebjornsson, basalt fibre bars as reinforcement for concrete, NordMin workshop, On- and Offshore Exploration and Prospecting in Extreme Nordic Environments. Challenges and Benefits of Finding Exploitable Raw Materials. Reykjavik 23-24 March, 2015.

Guarnieri, P., Brethes, A., Rasmussen, T. M., Bauer, T., Blischke, A., Erlendsson, Ö. (2016, November). Crustal Structure and Mineral Deposit Systems in central East Greenland (NordMin CRUSMID-3D). Presented at the Nordmin Nordic 3D geological modelling workshop - Trondheim, Norway.

\subsection{Posters}

Andri Gunnarsson, Eythor Rafn Thorhallsson and Jónas Pór Snæbjörnsson: Bearing capacity of prestressed BFRP reinforced concrete beams Experimental testing \& Finite element simulations. COST meeting Kaiserslautern, 2014.

Todor Zhelyazov, Eythor Thorhallsson and Jónas Snæbjörnsson. (2015). The mechanical response of Basalt Fibre Reinforced Polymer external reinforcement of cylindrical concrete elements loaded in compression. Cost Action TU1207 meeting in Lecce, Italy, 19-21 May, 2015. 
Iveta Novákováa, Eythor Thorhallsson, Application of Basalt fibres for an enhancement of fire resistance and freeze-thaw durability, COST Action TU1207 meeting in Prague, 2-4 November, 2016.

Poster presentation October 1, 2014 at ENERO (European Network of Environmental Research Organizations, www.enero.eu) 5th Scientific Work Shop, Environment in Horizon 2020, Fostering future integration of Environment \& Innovation (prepared by the project group, presented by Tiina Pajula, VTT).

\subsection{Theses}

Brethes, A., PhD thesis "Crustal structure and mineralization systems in Jameson Land, central East Greenland: an integrated analysis of geological, aeromagnetic and electromagnetic data". For submission in April, 2016.

Benedikt Rafnsson, Blápráđaframleiðsla á Íslandi. BSc thesis (in Icelandic) Reykjavik University, 2014.

Guðmundur I. Hinriksson, Glulam beams strengthened with pre-stressed basalt fibres, Reykjavik University (2016) MSc thesis.

Sigurður Halldór Örnólfsson; Yfirborðsmeðhöndlun asfaltbundinna slitlaga, BSc thesis (in Icelandic) Reykjavik University, 2016.

Stefán Ingi Björnsson; Steypt útveggjaklæðning með basaltbendingu, BSc thesis (in Icelandic) Reykjavik University, 2016.

Guðmundur Úlfar Gíslason; Veðurkápa á forsteyptum útveggjaeiningum með basalttrefjabendingu, BSc thesis (in Icelandic) Reykjavik University, 2016.

Arni B Arnason, Hekla Pumice, NordMin workshop. On- and Offshore Exploration and Prospecting in Extreme Nordic Environments. Challenges and Benefits of Finding Exploitable Raw Materials. Reykjavik 23-24 March, 2015.

Industrial supervision on a B.Sc. thesis:

Benedikt Rafnsson, Blápráđaframleiðsla á Íslandi. B.Sc thesis (in Icelandic) Reykjavik University, 2014 .

\subsection{NordMin commissioned}

Guarnieri et al. (2016). CRUSMID-3D final report. NCM TemaNord publication TN2016:562, $174 \mathrm{pp}$. Hojem, P. (2015). Mining in the Nordic Countries: A comparative review of legislation and taxation. TemaNord 2015:542. 84 pp. https://doi.org/10.6027/tn2015-542

Johannesson et al. (2016). GREENBAS final report. TemaNord publication TN2016:564, 61 pp. Nordic Council of Ministers (2014). A Nordic Network of Expertise for a Sustainable Mining and Mineral Industry. ISBN 978-92-893-2698-8. DOI http://dxdoi.org/10.6027/ANP2014-714. ANP 2014:714. 16 pp.

Ranängen et al. (2016). A path towards sustainability for the Nordic mining industry. TemaNord publication TN2016:56o, $96 \mathrm{pp}$.

Wahlström et al. (2017). WASCIOUS final report. NCM TemaNord publication TN2017:525, 195 pp. 


\section{NordMin: Ett nordiskt nätverk för en hållbar gruv- och mineralindustrin}

NordMin startade 2013 som ett projekt inom ramen för Nordiska ministerrådet i syfte att stärka samarbetet för en hållbar gruv- och mineralindustrin i Norden.

NordMin initierades av det svenska ordförandeskapet i Nordiska rådet som ett strategiskt initiativ med en löptid på fyra år.

Luleå tekniska universitet har varit projektledare och ett antal aktiviteter har rullats ut under de senaste åren.

NordMin har haft följande centrala verksamhetsområden:

1. Nordiska forskning och innovationprojekt.

2. Seminarier inom relavanta teman för att definiera gemensamma nordiska aktiviteter.

3. Nordiska förstudieprojekt för att ta fram förslag till forskningsprojekt för att växla upp nordisk finansiering.

4. Doktorand/forskarkurser inom relevanta teman.

5. Rapporter om hållbarhetskriterier i ett nordiskt perspektiv.

Syftet med denna rapport är att ge en mycket kortfattad översikt över NordMins aktiviteter och även att dra några slutsatser om vad som har uppnåtts när det gäller nordiskt samarbete inom området och hur vi kan dra nytta av detta i framtiden.

De stora utmaningarna inom sektorn återstår: råvaruförsörjning, hållbar utveckling i Arktis, energilösningar för ett koldioxidsnålt samhälle och klimatförändringar. Alla dessa frågor är intimt relaterade till gruvsektorn i Norden och NordMin var ett första steg mot att finna en gemensam nordisk agenda inom området hållbar utvinning av metaller och mineral. 
Nordic Council of Ministers

Ved Stranden 18

DK-1061 Copenhagen K

www.norden.org

\section{NORDMIN 2013-2017}

NordMin started in 2013 as a project under the auspices of the Nordic Council of Ministers with the aim to strengthen Nordic collaboration for a sustainable Mining and Minerals industry in the Nordic countries.

NordMin was initiated by the Swedish chairmanship of the Nordic Council as a strategic initiative with a duration of 4 years.

The project management has been hosted by Luleå University of Technology and a number of activities have been rolled out over the last few years.

The aim of this report is to give a brief overview of NordMin activities and also to draw some final conclusions on what has been achieved in terms of a closer Nordic collaboration within the field and how we can benefit from this in the future.

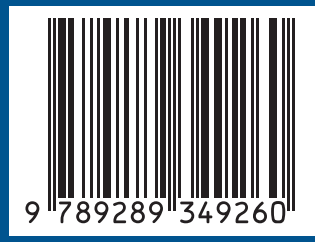

